\title{
Radiative forcing since preindustrial times due to ozone change in the troposphere and the lower stratosphere
}

\author{
M. Gauss ${ }^{1}$, G. Myhre ${ }^{1}$, I. S. A. Isaksen ${ }^{1}$, V. Grewe ${ }^{2}$, G. Pitari ${ }^{3}$, O. Wild ${ }^{4}$, W. J. Collins ${ }^{5}$, F. J. Dentener ${ }^{6}$, K. Ellingsen ${ }^{1}$, \\ L. K. Gohar ${ }^{7}$, D. A. Hauglustaine ${ }^{8}$, D. Iachetti ${ }^{3}$, J.-F. Lamarque ${ }^{9}$, E. Mancini ${ }^{3}$, L. J. Mickley ${ }^{10}$, M. J. Prather ${ }^{11}$, \\ J. A. Pyle ${ }^{12}$, M. G. Sanderson ${ }^{5}$, K. P. Shine ${ }^{7}$, D. S. Stevenson ${ }^{13}$, K. Sudo ${ }^{4}$, S. Szopa ${ }^{8}$, and G. Zeng ${ }^{12}$ \\ ${ }^{1}$ Department of Geosciences, University of Oslo, Oslo, Norway \\ ${ }^{2}$ Institut für Physik der Atmosphäre, DLR, Oberpfaffenhoffen, Germany \\ ${ }^{3}$ Dipartimento di Fisica, Università de L'Aquila, Coppito, L'Aquila, Italy \\ ${ }^{4}$ Frontier Research Center for Global Change, JAMSTEC, Yokohama, Japan \\ ${ }^{5}$ Hadley Centre, Met Office, Exeter, Devon, UK \\ ${ }^{6}$ Climate Change Unit, Joint Research Centre, Ispra, Italy \\ ${ }^{7}$ Department of Meteorology, University of Reading, Reading, UK \\ ${ }^{8}$ Laboratoire des Sciences du Climat et de L'Environnement (LSCE), Gif-sur-Yvette, France \\ ${ }^{9}$ Atmospheric Chemistry Division, NCAR, Boulder, Colorado, USA \\ ${ }^{10}$ Division of Engineering and Applied Sciences, Harvard University, Cambridge, Massachusetts, USA \\ ${ }^{11}$ Earth System Science Department, University of California at Irvine, USA \\ ${ }^{12}$ Cambridge University, Chemistry Department, Cambridge, UK \\ ${ }^{13}$ School of Geosciences, University of Edinburgh, Edinburgh, UK
}

Received: 1 July 2005 - Published in Atmos. Chem. Phys. Discuss.: 10 August 2005

Revised: 7 December 2005 - Accepted: 13 January 2006 - Published: 24 February 2006

\begin{abstract}
Changes in atmospheric ozone have occurred since the preindustrial era as a result of increasing anthropogenic emissions. Within ACCENT, a European Network of Excellence, ozone changes between 1850 and 2000 are assessed for the troposphere and the lower stratosphere (up to $30 \mathrm{~km}$ ) by a variety of seven chemistry-climate models and three chemical transport models. The modeled ozone changes are taken as input for detailed calculations of radiative forcing.

When only changes in chemistry are considered (constant climate) the modeled global-mean tropospheric ozone column increase since preindustrial times ranges from 7.9 DU to $13.8 \mathrm{DU}$ among the ten participating models, while the stratospheric column reduction lies between 14.1 DU and 28.6 DU in the models considering stratospheric chemistry. The resulting radiative forcing is strongly dependent on the location and altitude of the modeled ozone change and varies between $0.25 \mathrm{Wm}^{-2}$ and $0.45 \mathrm{Wm}^{-2}$ due to ozone change in the troposphere and $-0.123 \mathrm{Wm}^{-2}$ and $+0.066 \mathrm{Wm}^{-2}$ due to the stratospheric ozone change.
\end{abstract}

Correspondence to: M. Gauss

(michael.gauss@geo.uio.no)
Changes in ozone and other greenhouse gases since preindustrial times have altered climate. Six out of the ten participating models have performed an additional calculation taking into account both chemical and climate change. In most models the isolated effect of climate change is an enhancement of the tropospheric ozone column increase, while the stratospheric reduction becomes slightly less severe. In the three climate-chemistry models with detailed tropospheric and stratospheric chemistry the inclusion of climate change increases the resulting radiative forcing due to tropospheric ozone change by up to $0.10 \mathrm{Wm}^{-2}$, while the radiative forcing due to stratospheric ozone change is reduced by up to $0.034 \mathrm{Wm}^{-2}$.

Considering tropospheric and stratospheric change combined, the total ozone column change is negative while the resulting net radiative forcing is positive.

\section{Introduction}

Tropospheric ozone concentrations have increased since the preindustrial era due to anthropogenic emissions of ozone 
precursors, such as nitrogen oxides $\left(\mathrm{NO}_{\mathrm{x}}\right)$, carbon monoxide $(\mathrm{CO})$, methane $\left(\mathrm{CH}_{4}\right)$, and non-methane hydrocarbons (NMHC) (Bojkov, 1986; Volz and Kley, 1988; Marenco, 1994). Numerous model studies quantifying this ozone increase have been published (e.g. Berntsen et al., 1997; Stevenson et al., 1998; Mickley et al., 1999; Hauglustaine and Brasseur, 2001; Shindell et al., 2003; Wong et al., 2004; Lamarque et al., 2005). In the stratosphere, ozone depletion has occurred during the last few decades, primarily through catalytic cycles involving chlorine and bromine species, both of which have been enhanced by human activity (WMO, 2003). Stolarski et al. (1992) found from satellite and ground-based measurements that the ozone decreases are taking place mostly in the lower stratosphere in the region of highest ozone concentration. Stratospheric ozone changes have implications for the troposphere as well, primarily through changes in the downward cross-tropopause transport of ozone and through alterations of the actinic flux. In a recent study, Zerefos (2002) analyzed long-term measurements of UV at Thessaloniki, finding increases of solar UV irradiance by more than $10 \%$ per decade for the period 1979-1997 and clearly relating them to reductions of midlatitude column ozone. Isaksen et al. (2005) investigated the significance of stratospheric ozone change for tropospheric chemistry through changes in the actinic flux. Stratospheric ozone reduction was found to increase near-surface ozone in polluted areas while reducing it in remote areas.

With regard to climate change, ozone affects the radiative budget of the atmosphere through its interaction with both shortwave (SW) and longwave (LW) radiation and its chemical influence on other radiatively active trace gases such as methane and HCFCs. Radiative forcing is commonly defined as the imbalance in radiative flux at the tropopause resulting from a perturbation in the atmosphere, in order to determine the relative importance of different greenhouse gases and aerosols to climate. Connected with the absorption of solar SW radiation and the absorption and emission of LW radiation, reductions in lower stratospheric ozone imply a positive SW and a negative LW radiative forcing, while tropospheric ozone increases lead to a positive radiative forcing in both the SW and LW spectral regions. Several publications have established the strong dependence of radiative forcing on the altitude (Wang and Sze, 1980; Lacis et al., 1990; Forster and Shine, 1997; Hansen et al., 1997) and the horizontal distribution (Berntsen et al., 1997) of the ozone change. There are inadequate observations of the changes in tropospheric ozone on a global scale, even for recent decades, and this necessitates the use of models to estimate the changes. As ozone exhibits a highly spatially inhomogeneous distribution, 3-D atmospheric models have been applied to estimate its global radiative forcing. In the past, several calculations of radiative forcing due to tropospheric ozone increase since the preindustrial era have been published (e.g. Kiehl et al., 1999; Berntsen et al., 2000; Hauglustaine and Brasseur, 2001; Mickley et al., 2001). Chapter 6 of the IPCC Third
Assessment Report (IPCC-TAR) (Ramaswamy et al., 2001) reports a radiative forcing of $0.35 \pm 0.15 \mathrm{Wm}^{-2}$ for the period 1750 to 1998 , ranking ozone as a climate forcing gas in third place after carbon dioxide and methane.

Radiative forcing owing to ozone loss in the lower stratosphere has been studied, for example, by Forster (1999), Kiehl et al. (1999), and Myhre et al. (2001), and is a complex balance between the negative LW and the positive SW contributions. The IPCC-TAR estimates the net radiative forcing due to stratospheric ozone loss since preindustrial times at $-0.15 \pm 0.1 \mathrm{Wm}^{-2}$. Unlike the tropospheric ozone forcing calculations, these estimates have been mostly derived from observed ozone changes.

Chemistry-climate feedback mechanisms have been discussed in various publications (e.g. Granier and Shine, 1999; Grewe et al., 2001a; Isaksen et al. 2003; Stevenson et al., 2005). Major identified feedback mechanisms include the change of chemical reaction rates due to temperature change, the enhanced photochemical destruction of tropospheric ozone related to increased humidity, changes in lightning emissions, and possibly further stratospheric ozone depletion due to enhanced heterogeneous processing in a cooling stratosphere. Climate change may also alter the general circulation of the atmosphere and dynamical processes on smaller scales, such as boundary layer ventilation, convection activity, and stratosphere-troposphere exchange. These considerations suggest that climate change should be considered in model studies of ozone change over long periods of time.

Within Integrating Activity 3 of the European Network of Excellence, ACCENT ("Atmospheric Composition Change: the European NeTwork of excellence"), a large number of research groups involved in 3-D atmospheric modeling have been invited to participate in two comprehensive assessments of atmospheric composition change. While most of the studies performed within this effort focus on tropospheric composition change to be expected for the near future (year 2030) (e.g. Dentener et al., 2006 ${ }^{1}$; Stevenson et al., 2006; Ellingsen et al., 2006 ${ }^{2}$; van Noije et al., 2006) the study presented in

\footnotetext{
${ }^{1}$ Dentener, F., Stevenson, D., Ellingsen, K., van Noije, T., Schultz, M., Amann, M., Atherton, C., Bell, N., Bergmann, D., Bey, I., Bouwman, L., Butler, T., Cofala, J., Collins, B., Drevet, J., Doherty, R., Eickhout, B., Eskes, H., Fiore, A., Gauss, M., Hauglustaine, D., Horowitz, L., Isaksen, I., Josse, B., Lawrence, M., Krol, M., Lamarque, J. F., Montanaro, V., Müller, J. F., Peuch, V. H., Pitari, G., Pyle, J., Rast, S., Rodriguez, J., Sanderson, M., Savage, N., Shindell, D., Strahan, S., Szopa, S., Sudo, K., Wild, O., and Zeng, G.: The global atmospheric environment for the next generation, Environ. Sci. Technol., in review, 2006.

${ }^{2}$ Ellingsen, K., Van Dingenen, R., Dentener, F. J., Emberson, L., Fiore, A. M., Schultz, M. G., Stevenson, D. S., Gauss, M., Amann, M., Atherton, C. S., Bell, N., Bergmann, D. J., Bey, I., Butler, T., Cofala, J., Collins, W. J., Derwent, R. G., Doherty, R. M., Drevet, J., Eskes, H., Hauglustaine, D., Isaksen, I. S. A., Horowitz, L. W., Krol, M., Lamarque, J. F., Lawrence, M., Montanaro, V., Müller,
} 
this paper deals with ozone change since preindustrial times in the troposphere and the lower stratosphere. The main idea and novelty is to include both tropospheric and stratospheric chemistry and to account for climate change, including couplings between chemistry and climate, in a multimodel study. Time-slice model simulations have been carried out for the years 1850 and 2000, yielding ozone change that is taken as input for detailed radiative transfer calculations. The applied models greatly differ in transport and chemistry schemes, parameterizations of sub-scale processes and microphysics, and meteorological data. Some of the models take into account climate change, while others use the same meteorology for both time slices. Some of the models include detailed chemistry for both the troposphere and the stratosphere, while others focus on the troposphere only.

The spatial distribution of radiative forcing is calculated for the ten sets of model data by three different radiative transfer models developed at the Universities of Oslo, L'Aquila, and Reading, respectively, distinguishing between the LW and SW contributions. For comparison, we also present results from a similar study that has been made at Harvard University based on ozone changes calculated by the Harvard-GISS chemical transport model.

In the following section we briefly describe the participating atmospheric composition models, evaluate their ability to model ozone for the year 2000, and present modeled ozone change since preindustrial times. In Sect. 3 we present the results of the radiative transfer calculations, followed by concluding remarks and suggested future directions in Sect. 4.

\section{Atmospheric composition change}

\subsection{Description of models}

We have used seven coupled chemistry-climate models (CCMs) and three chemical transport models (CTMs) to calculate atmospheric composition change since the preindustrial era (1850). The main features of these models are summarized in Table 1. The horizontal resolution is highly variable between the models, ranging from a Gaussian T42 grid $\left(2.8^{\circ} \times 2.8^{\circ}\right)$ to a regular grid of $10^{\circ}$ latitude $\times 22.5^{\circ}$ longitude. Also, the vertical resolutions vary among the models and with altitude, and the upper boundaries range from $100 \mathrm{hPa}(\sim 16 \mathrm{~km})$ to $0.004 \mathrm{hPa}(\sim 85 \mathrm{~km})$. The CTMs use meteorological data either from their underlying GCM (STOCHEM_HadAM3) or from European Centre for Medium-range Weather Forecasts (ECMWF) data (UIO_CTM2 and FRSGC_UCI), while the CCMs calculate the model meteorology on-line and account for couplings be-

\footnotetext{
J. F., van Noije, T., Pitari, G., Prather, M. J., Pyle, J., Rast, S., Rodriguez, J., Sanderson, M., Savage, N., Shindell, D., Strahan, S., Sudo, K., Szopa, S., Wild, O., and Zeng, G.: Ozone air quality in 2030: a multi-model assessment of risks for health and vegetation, in preparation, 2006.
}

tween climate and radiatively active chemical species and/or aerosols to different degrees of complexity. A large variety of transport and convection schemes is used, which are described in detail elsewhere (see references in Table 1). All models integrate tropospheric ozone chemistry, but with varying comprehensiveness, especially with regard to non-methane hydrocarbon chemistry. In the stratosphere, four models apply comprehensive chemistry schemes (ULAQ, DLR_E39C, NCAR_MACCM, and UIO_CTM2). In CHASER, stratospheric ozone trends are prescribed using the method of Randel and Wu (1999) with effective equivalent stratospheric chlorine loadings corresponding to the specifications of this experiment (see Sect. 2.2). FRSGC_UCI uses linearized ozone chemistry following Mc Linden et al. (2000). The other models prescribe or nudge ozone based on climatological data.

Detailed evaluations of the models used in this study are found in the scientific literature (see references in Table 1). For this study an evaluation has been made for zonal-mean ozone against the Fortuin and Kelder (1998) ozone climatology (hereafter referred to as FK98), which is based on ozonesonde and satellite measurements made between 1980 and 1991. Although the number of ozonesonde stations used in FK98 is quite limited and its considered time period is up to 20 years before the year 2000, FK98 appears to be the best available climatology for multi-model evaluations focusing ozone in the upper troposphere and lower stratosphere on a global scale.

Zonal-mean ozone distributions along with the relative deviations for each model are displayed in Fig. 1. For the year 2000 simulation the models were allowed to use their own, well-tested, emissions. This approach allows for a better judgment of the current uncertainty within the model community. The ozone mixing ratio modeled for the year 2000 (Fig. 1a) amounts to a few tens of ppbv at the surface and increases with altitude. In low latitudes, vertical transport of relatively low ozone air through convection and advection deflects the ozone contour lines upwards. Differences among the models are explained not only by differences in the chemistry modules, but also in long range transport from the main emission sources into remote areas, where ozone production is more efficient. Following the pattern of emissions, surface ozone is a maximum in mid- to high northern latitudes, amounting to $30-50 \mathrm{ppbv}$ on a zonal and annual mean. Monthly-mean distributions (not shown) show maxima in surface ozone exceeding $90 \mathrm{ppbv}$ during the summer season in the polluted regions of the North-Eastern United States, Europe and the Far-East connected with industrial emissions, and over Central Africa connected with biomass burning.

By and large, the comparison with the FK98 observational data set reveals relatively good simulations of the global scale chemical features of the current atmosphere evidenced by ozone (Fig. 1b). Part of the deviations may be explained by the fact that some models use meteorological data for 

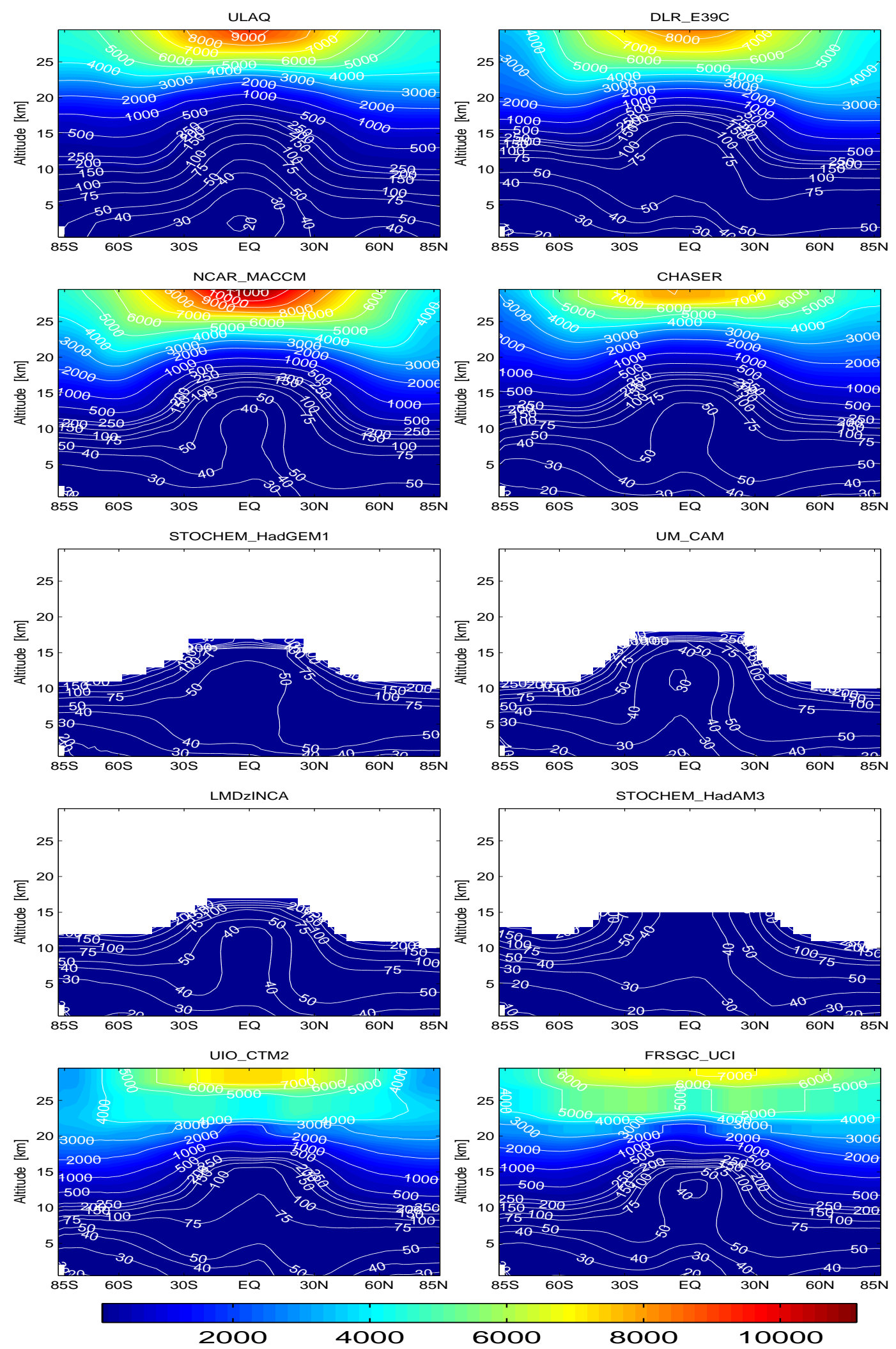

Fig. 1. Annually averaged (a) modeled zonal-mean ozone distribution (ppbv) in the year 2000 simulation (scenario 2), (b) percent deviation from Fortuin and Kelder (1998) climatology (i.e. (model-climatology)/climatology $\times 100$ ). The stratosphere (taken as ozone $>150 \mathrm{ppbv}$ in year 2000) is masked for the models that do not calculate stratospheric chemistry explicitly. 

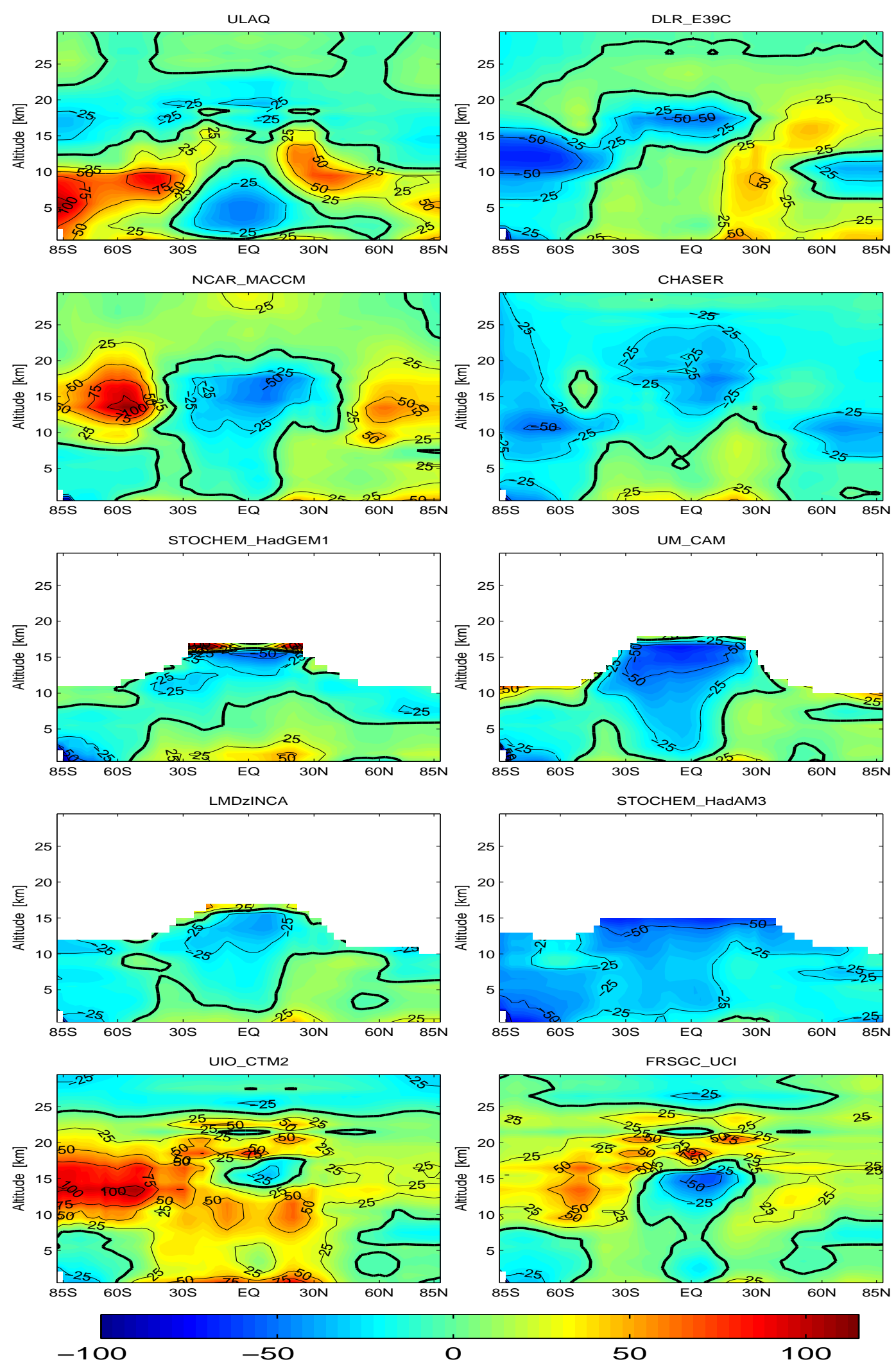

Fig. 1. Continued. 
Table 1. Description of models.

\begin{tabular}{|c|c|c|c|c|}
\hline Number/Name/Type & Institute & Investigator(s) & Domain/Resolution & Underlying GCM/Meteorology \\
\hline $\begin{array}{l}1 \\
\text { ULAQ } \\
\text { CCM }\end{array}$ & University of L'Aquila & $\begin{array}{l}\text { D. Iachetti } \\
\text { G. Pitari } \\
\text { E. Mancini }\end{array}$ & $\begin{array}{l}22.5^{\circ} \text { lon } \times 10^{\circ} \text { lat } \\
26 \text { levels } \\
\text { sfc }-0.04 \mathrm{hPa}\end{array}$ & $\begin{array}{l}\text { ULAQ-GCM (Pitari, 1993; } \\
\text { Pitari et al., 2002) }\end{array}$ \\
\hline $\begin{array}{l}2 \\
\text { DLR_E39C } \\
\text { CCM }\end{array}$ & $\begin{array}{l}\text { DLR Oberpfaffenhofen, } \\
\text { Germany }\end{array}$ & V. Grewe & $\begin{array}{l}\mathrm{T} 30\left(3.8^{\circ} \times 3.8^{\circ}\right) \\
39 \text { levels } \\
\text { sfc }-10 \mathrm{hPa}\end{array}$ & GCM (ECHAM) \\
\hline $\begin{array}{l}3 \\
\text { NCAR_MACCM } \\
\text { CCM }\end{array}$ & NCAR Boulder & J.-F. Lamarque & $\begin{array}{l}5^{\circ} \text { lon } \times 4^{\circ} \text { lat } \\
52 \text { levels } \\
\text { sfc }-85 \mathrm{~km}\end{array}$ & GCM (NCAR) \\
\hline $\begin{array}{l}4 \\
\text { CHASER } \\
\text { CCM }\end{array}$ & FRSGC/JAMSTEC & K. Sudo & $\begin{array}{l}\mathrm{T} 42\left(2.8^{\circ} \times 2.8^{\circ}\right) \\
32 \text { levels } \\
\text { sfc }-3 \mathrm{hPa}\end{array}$ & GCM (CCSR/NIES) \\
\hline $\begin{array}{l}5 \\
\text { STOCHEM_HadGEM1 } \\
\text { CCM }\end{array}$ & UK Met Office & $\begin{array}{l}\text { M. Sanderson } \\
\text { B. Collins }\end{array}$ & $\begin{array}{l}3.8^{\circ} \text { lon } \times 2.5^{\circ} \text { lat } \\
20 \text { levels } \\
\text { sfc }-40 \mathrm{~km}\end{array}$ & GCM (HadGEM) \\
\hline $\begin{array}{l}6 \\
\text { UM_CAM } \\
\text { CCM }\end{array}$ & Cambridge University & $\begin{array}{l}\text { G. Zeng } \\
\text { J. Pyle }\end{array}$ & $\begin{array}{l}3.8^{\circ} \text { lon } \times 2.5^{\circ} \text { lat } \\
19 \text { levels } \\
\mathrm{sfc}-4.6 \mathrm{hPa}\end{array}$ & $\begin{array}{l}\text { GCM (UKMO Unified } \\
\text { Model version } 4.5 \text { ) }\end{array}$ \\
\hline $\begin{array}{l}7 \\
\text { LMDzINCA } \\
\text { CCM }\end{array}$ & IPSL/LSCE & $\begin{array}{l}\text { D. Hauglustaine } \\
\text { S. Szopa }\end{array}$ & $\begin{array}{l}3.8^{\circ} \text { lon } \times 2.5^{\circ} \text { lat } \\
19 \text { levels } \\
\text { sfc }-3 \mathrm{hPa}\end{array}$ & $\begin{array}{l}\text { GCM, or nudged to ECMWF: } \\
\text { ERA15, ERA40, } \\
\text { Operational Data (OD) }\end{array}$ \\
\hline $\begin{array}{l}8 \\
\text { STOCHEM_HadAM3 } \\
\text { CTM }\end{array}$ & University of Edinburgh & D. Stevenson & $\begin{array}{l}5^{\circ} \times 5^{\circ} \\
9 \text { levels } \\
\text { sfc }-100 \mathrm{hPa}\end{array}$ & GCM (HadAM3) \\
\hline $\begin{array}{l}9 \\
\text { UIO_CTM2 } \\
\text { CTM }\end{array}$ & University of Oslo & $\begin{array}{l}\text { M. Gauss } \\
\text { I. Isaksen }\end{array}$ & $\begin{array}{l}\mathrm{T} 42\left(2.8^{\circ} \times 2.8^{\circ}\right) \\
40 \text { levels } \\
\mathrm{sfc}-10 \mathrm{hPa}\end{array}$ & $\begin{array}{l}\text { ECMWF: Integrated Forecast } \\
\text { System (IFS) pieced-forecast } \\
\text { data for } 2000\end{array}$ \\
\hline $\begin{array}{l}10 \\
\text { FRSGC_UCI } \\
\text { CTM }\end{array}$ & FRSGC/JAMSTEC & O. Wild & $\begin{array}{l}\mathrm{T} 42\left(2.8^{\circ} \times 2.8^{\circ}\right) \\
37 \text { levels } \\
\text { sfc }-10 \mathrm{hPa}\end{array}$ & $\begin{array}{l}\text { ECMWF: IFS } \\
\text { pieced-forecast } \\
\text { data for } 2000\end{array}$ \\
\hline
\end{tabular}

one specific year (e.g. 2000), while FK98 represents a climatology typical of the period 1980-1991. Furthermore, the time lag between the 1980s and the year 2000 implies that FK98 does not account for the additional ozone depletion that occurred during the 1990s (WMO, 2003). This partly explains the lower ozone mixing ratios in the models ULAQ, DLR_E39C, and CHASER in the stratosphere in high southern latitudes.

Local maxima in the deviation are also seen in the tropical tropopause region, which is largely influenced by convective processes. Convection, in turn is treated differently by the models, which contributes to the different behavior of the models in that region. Also, small shifts in the tropopause height lead to large relative deviations in the zonal mean distribution in the upper troposphere/lower stratosphere region. Shifts in the tropopause height can solely arise from systematic biases in the dynamics (e.g. temperature cold bias). Generally, an inter-comparison relative to the tropopause height reveals a better representation of tropospheric and stratospheric simulated ozone (Grewe et al., 2001b). In order to avoid misleading interpretations, we concentrate here on regions with a more uniform dynamical characterization. Tropical tropospheric ozone $(0-12 \mathrm{~km}, 20 \mathrm{~N}-20 \mathrm{~S})$ is simulated within $\pm 40 \%$ by all models except UIO_CTM2 
Table 1. Continued.

\begin{tabular}{|c|c|c|c|c|}
\hline Number/Name/Type & Advection Scheme & Convection Scheme & Tropospheric Chemistry & Stratospheric Chemistry \\
\hline $\begin{array}{l}1 \\
\text { ULAQ } \\
\text { CCM }\end{array}$ & $\begin{array}{l}\text { Eulerian explicit } \\
\text { (Pitari et al., 1997) }\end{array}$ & $\begin{array}{l}\text { Pitari et al. (2002) } \\
\text { following Müller and } \\
\text { Brasseur (1995) }\end{array}$ & $\begin{array}{l}\text { NMHC, PAN, S chemistry, } \\
\text { tropospheric aerosols and } \\
\text { ozone }\end{array}$ & $\begin{array}{l}\text { Ozone calculated by de- } \\
\text { tailed stratospheric chemistry } \\
\text { scheme, including aerosols }\end{array}$ \\
\hline $\begin{array}{l}2 \\
\text { DLR_E39C } \\
\text { CCM }\end{array}$ & $\begin{array}{l}\text { Semi-Lagrangian } \\
\text { (Williamson and } \\
\text { Rasch, 1994) }\end{array}$ & $\begin{array}{l}\text { Mass flux scheme of } \\
\text { Tiedke (1989) }\end{array}$ & $\begin{array}{l}\text { Methane oxidation } \\
\text { Dry/wet deposition } \\
37 \text { species, } 12 \text { advected }\end{array}$ & $\begin{array}{l}\text { Heterogeneous } \mathrm{Cl} \text { reactions, } \\
\text { PSC I, II, aerosols }\end{array}$ \\
\hline $\begin{array}{l}3 \\
\text { NCAR_MACCM } \\
\text { CCM }\end{array}$ & $\begin{array}{l}\text { Lin and Rood } \\
\text { scheme (Lin and } \\
\text { Rood, 1996) }\end{array}$ & $\begin{array}{l}\text { Deep: Zhang and Mc- } \\
\text { Farlane (1995), shal- } \\
\text { low: Hack (1994) }\end{array}$ & $\begin{array}{l}\text { Detailed } \\
\text { ozone/CO/NO } / \mathrm{HOx} / \mathrm{NMHC}\end{array}$ & $\begin{array}{l}\text { Detailed stratospheric chem- } \\
\text { istry, including aerosols }\end{array}$ \\
\hline $\begin{array}{l}4 \\
\text { CHASER } \\
\text { CCM }\end{array}$ & $\begin{array}{l}\text { Lin and Rood } \\
\text { scheme (Lin and } \\
\text { Rood, 1996) }\end{array}$ & $\begin{array}{l}\text { prognostic Arakawa- } \\
\text { Schubert scheme } \\
\text { (Emori et al., 2001) }\end{array}$ & $\begin{array}{l}\text { Detailed ozone-NO } \mathrm{N}_{\mathrm{x}}-\mathrm{NMHC} \\
\text { chemistry, } 53 \text { species, } 140 \text { re- } \\
\text { actions, incl. on-line sulfate }\end{array}$ & $\begin{array}{l}\text { Ozone mixing ratio relaxed } \\
\text { above } 50 \mathrm{hPa} \text { to prescribed } \\
\text { data }\end{array}$ \\
\hline $\begin{array}{l}5 \\
\text { STOCHEM_HadGEM1 } \\
\text { CCM }\end{array}$ & $\begin{array}{l}\text { Lagrangian } \\
\text { (Collins et al., } \\
\text { 1997) }\end{array}$ & $\begin{array}{l}\text { Described in Collins } \\
\text { et al. }(2002)\end{array}$ & $\begin{array}{l}\text { Detailed } \\
\text { ozone/ } \mathrm{NO}_{\mathrm{x}} / \text { hydrocarbon } \\
\text { scheme including } 70 \text { species }\end{array}$ & $\begin{array}{l}\text { Relaxed towards SPARC cli- } \\
\text { matology above tropopause }\end{array}$ \\
\hline $\begin{array}{l}6 \\
\text { UM_CAM } \\
\text { CCM }\end{array}$ & $\begin{array}{l}\text { Eulerian } \\
\text { Leonard } \\
\text { al. (1995) }\end{array}$ & $\begin{array}{l}\text { Penetrative mass flux } \\
\text { Gregory and Rown- } \\
\text { tree (1990) }\end{array}$ & $\begin{array}{l}\mathrm{NO}_{\mathrm{x}}-\mathrm{CO}-\mathrm{CH}_{4}-\mathrm{NMHCs} \\
\text { species, } 36 \text { advected })\end{array}$ & $\begin{array}{l}\mathrm{O}_{3} \text { and } \mathrm{NO}_{\mathrm{y}} \text { are prescribed } \\
\text { above } 30 \mathrm{hPa}\left(\mathrm{NO}_{\mathrm{x}} / \mathrm{HO}_{\mathrm{x}}\right. \\
\text { chemistry applies in the } \\
\text { stratosphere below } 30 \mathrm{hPa})\end{array}$ \\
\hline $\begin{array}{l}7 \\
\text { LMDzINCA } \\
\text { CCM }\end{array}$ & $\begin{array}{l}\text { Finite Volume } \\
\text { second order (Van } \\
\text { Leer, 1977) }\end{array}$ & $\begin{array}{l}\text { Mass flux scheme of } \\
\text { Tiedke (1989) }\end{array}$ & $\begin{array}{l}\text { Detailed ozone/CO/NO } / \text { hy- } \\
\text { drocarbon; } 303 \text { reactions and } \\
85 \text { species, implicit-Newton- } \\
\text { Raphson solver }\end{array}$ & $\begin{array}{l}\text { Stratospheric ozone nudged } \\
\text { towards climatology above } \\
380 \mathrm{~K}\end{array}$ \\
\hline $\begin{array}{l}8 \\
\text { STOCHEM_HadAM3 } \\
\text { CTM }\end{array}$ & $\begin{array}{l}\text { Lagrangian } \\
\text { (Collins et al., } \\
\text { 1997) }\end{array}$ & $\begin{array}{l}\text { Described in Collins } \\
\text { et al. (2002) }\end{array}$ & $\begin{array}{l}\text { Detailed ozone } / \mathrm{NO}_{\mathrm{x}} / \text { hydro- } \\
\text { carbon scheme including } 70 \\
\text { species }\end{array}$ & $\begin{array}{l}\text { Prescribed ozone concentra- } \\
\text { tion gradient at } 100 \mathrm{hPa}\end{array}$ \\
\hline $\begin{array}{l}9 \\
\text { UIO_CTM2 } \\
\text { CTM }\end{array}$ & $\begin{array}{l}\text { Second Order } \\
\text { Moments (Prather, } \\
\text { 1986) }\end{array}$ & $\begin{array}{l}\text { Mass flux scheme of } \\
\text { Tiedke (1989) }\end{array}$ & $\begin{array}{l}\text { Detailed } \\
\text { ozone/ } \mathrm{NO}_{\mathrm{x}} / \text { hydrocarbon } \\
\text { scheme including } 58 \text { species, } \\
\text { QSSA solver }\end{array}$ & $\begin{array}{l}\text { Detailed stratospheric chem- } \\
\text { istry including } \mathrm{Cl} / \mathrm{Br} \text {, hetero- } \\
\text { geneous chemistry on PSC } \\
\text { I/II, aerosols }\end{array}$ \\
\hline $\begin{array}{l}10 \\
\text { FRSGC_UCI } \\
\text { CTM }\end{array}$ & $\begin{array}{l}\text { Second } \begin{array}{l}\text { order } \\
\text { moment } \\
\text { (Prather, }\end{array} \\
\text { (986) }\end{array}$ & $\begin{array}{l}\text { Mass fluxes taken } \\
\text { from the ECMWF- } \\
\text { IFS fields }\end{array}$ & $\begin{array}{l}\text { Detailed Ox/HOx/NO } / \\
\text { CH4/VOC chemistry, } 35 \\
\text { species, using ASAD package } \\
\text { (Carver et al., 1997) }\end{array}$ & $\begin{array}{l}\text { LINOZ linearized ozone } \\
\text { chemistry (Mc Linden et al., } \\
2000 \text { ) }\end{array}$ \\
\hline
\end{tabular}

in comparison to FK98. Most of the models show a smaller ozone mixing ratio with a deviation ranging from -20 to $-30 \%$ (ULAQ, NCAR_MACCM, STOCHEM_HadGEM1, UM_CAM, LMDzINCA, STOCHEM_HadAM3, and FRSGC_UCI) and some a higher ozone mixing ratio typically in the range of $20 \%$ to $40 \%$ (DLR E39C, CHASER, UIO_CTM2). All models show a higher near-surface ozone concentration near the equator, which differently extends to higher altitudes. The Northern Hemisphere extra-tropical troposphere $(45 \mathrm{~N}-90 \mathrm{~N}, 0-8 \mathrm{~km})$ is simulated within $\pm 30 \%$ (ULAQ and DLR) and $\pm 10-20 \%$ (all other models), generally being in better agreement than in the tropical region. However, there are a number of limitations to this inter-comparison. Firstly, the low-latitude surface measurements are made primarily in remote areas rather than in the most prominent biomass burning areas, which may account for the systematic higher modeled ozone values. Secondly, the horizontal pattern of the emissions is not changing with time, except for the seasonal cycle for biomass burning and represents in most cases a specific year, which cannot correctly represent the respective time period of the FK98 observational dataset. Furthermore, the 
Table 1. Continued.

\begin{tabular}{|c|c|c|}
\hline Number/Name/Type & Coupling Chemistry-Dynamics & References \\
\hline $\begin{array}{l}1 \\
\text { ULAQ } \\
\text { CCM }\end{array}$ & $\begin{array}{l}\text { Dynamical fields }(\mathrm{GCM} \rightarrow \mathrm{CTM}) \\
\text { and radiatively active species } \\
(\mathrm{CTM} \rightarrow \mathrm{GCM}): \mathrm{CO}_{2}, \mathrm{H}_{2} \mathrm{O}, \mathrm{CH}_{4} \text {, } \\
\mathrm{O}_{3}, \mathrm{~N}_{2} \mathrm{O}, \mathrm{CFCs}, \mathrm{HCFCs} \text {, aerosols }\end{array}$ & Pitari et al. (2002) \\
\hline $\begin{array}{l}2 \\
\text { DLR_E39C } \\
\text { CCM }\end{array}$ & $\mathrm{O}_{3}, \mathrm{H}_{2} \mathrm{O}, \mathrm{CH}_{4}, \mathrm{~N}_{2} \mathrm{O}, \mathrm{CFCs}$ & $\begin{array}{l}\text { Hein et al. (2001), Dameris et } \\
\text { al. (2005) }\end{array}$ \\
\hline $\begin{array}{l}3 \\
\text { NCAR_MACCM } \\
\text { CCM }\end{array}$ & $\mathrm{O}_{3}, \mathrm{H}_{2} \mathrm{O}, \mathrm{CH}_{4}, \mathrm{~N}_{2} \mathrm{O}, \mathrm{CFCs}$ & Boville et al. (1995) \\
\hline $\begin{array}{l}4 \\
\text { CHASER } \\
\text { CCM }\end{array}$ & $\mathrm{O}_{3}, \mathrm{H}_{2} \mathrm{O}, \mathrm{N}_{2} \mathrm{O}, \mathrm{CH}_{4},(\mathrm{CFCs})$ & Sudo et al. (2002a, b, 2003) \\
\hline $\begin{array}{l}5 \\
\text { STOCHEM_HadGEM1 } \\
\text { CCM }\end{array}$ & $\begin{array}{l}\text { one way coupling dynamics } \rightarrow \\
\text { chemistry through } \mathrm{NO}_{\mathrm{x}} \text { emissions } \\
\text { from lightning }\end{array}$ & Collins et al. $(1997,2003)$ \\
\hline $\begin{array}{l}6 \\
\text { UM_CAM } \\
\text { CCM }\end{array}$ & $\mathrm{O}_{3}, \mathrm{~N}_{2} \mathrm{O}, \mathrm{CH}_{4}, \mathrm{H}_{2} \mathrm{O}$ & Zeng and Pyle $(2003,2005)$ \\
\hline $\begin{array}{l}7 \\
\text { LMDzINCA } \\
\text { CCM }\end{array}$ & $\mathrm{H}_{2} \mathrm{O}$ & $\begin{array}{l}\text { Dufresne et al. (2002), Hauglus- } \\
\text { taine et al. (2004) }\end{array}$ \\
\hline $\begin{array}{l}8 \\
\text { STOCHEM_HadAM3 } \\
\text { CTM }\end{array}$ & Turned off & $\begin{array}{l}\text { Collins et al. (1997) } \\
\text { Stevenson et al. (2004) }\end{array}$ \\
\hline $\begin{array}{l}9 \\
\text { UIO_CTM2 } \\
\text { CTM }\end{array}$ & n.a. & Sundet (1997) \\
\hline $\begin{array}{l}10 \\
\text { FRSGC_UCI } \\
\text { CTM }\end{array}$ & n.a. & $\begin{array}{l}\text { Wild and Prather (2000), } \\
\text { Wild et al. (2003) }\end{array}$ \\
\hline
\end{tabular}

simulated general circulation is partly driven by sea surface temperatures, which are fixed to climatology in the models. This affects the NAO index, El Nino phenomenon, and other meteorological features, which in turn characterize long-range transports and thus atmospheric composition. Taking these limitations into account an agreement between modeled and observed ozone concentrations better than generally 20-40\% cannot be expected. In conclusion it can be said that, based on the measurement data used here, it is not possible to rank the models in terms of quality.

\subsection{Experimental setup}

Changes in tropospheric ozone since the 19th century have been driven mainly by increasing anthropogenic emissions of $\mathrm{NO}_{\mathrm{x}}, \mathrm{CH}_{4}, \mathrm{CO}$, and NMHCs, while stratospheric ozone depletion during the last three decades has been connected with increasing chlorine and bromine levels resulting from the use of CFCs, HCFCs, and halons. Climate change since preindustrial times has in part been caused by anthropogenic emissions of the greenhouse gases carbon dioxide $\left(\mathrm{CO}_{2}\right), \mathrm{CH}_{4}$, nitrous oxide $\left(\mathrm{N}_{2} \mathrm{O}\right)$, and $\mathrm{CFCs}$, and by changes in ozone. 
Table 2. Emissions and mixing ratios used for the year 2000 simulations. For $\mathrm{CO}_{2}$ mixing ratios used for 1850 are given in parentheses. Model numbering as in Table 1.

\begin{tabular}{|c|c|c|c|c|c|c|c|c|c|c|c|}
\hline Species & Model & 1 & 2 & 3 & 4 & 5 & 6 & 7 & 8 & 9 & 10 \\
\hline $\mathrm{NOx}$ & fossil fuel & 31.8 & 33.0 & 22.6 & 27.8 & 27.8 & 31.7 & 29.4 & 27.8 & 31.7 & 27.8 \\
\hline \multirow{5}{*}{$\operatorname{Tg}(\mathrm{N}) / \mathrm{yr}$} & biomass burning & 7.1 & 7.1 & 10.8 & 10.2 & 10.2 & 7.1 & 7.3 & 10.2 & 7.1 & 10.2 \\
\hline & aircraft & 0.7 & 0.7 & 0.7 & 0.6 & 0.8 & 0.7 & 0.6 & 0.8 & 0.7 & 0.7 \\
\hline & lightning & 5.0 & 5.3 & 5.0 & 5.0 & 5.7 & 4.0 & 5.0 & 7.0 & 5.0 & 5.0 \\
\hline & soil, natural & 5.5 & 5.6 & 6.5 & 5.5 & 5.6 & 5.4 & 8.7 & 5.6 & 5.6 & 5.5 \\
\hline & total & 50.1 & 53.2 & 45.6 & 49.1 & 50.1 & 48.9 & 51.0 & 51.4 & 50.1 & 49.2 \\
\hline \multirow{5}{*}{$\begin{array}{l}\mathrm{CO} \\
\mathrm{Tg}(\mathrm{CO}) / \mathrm{yr}\end{array}$} & vegetation & 150 & 1) & 156 & 0 & 130 & 150 & 0 & 75 & 150 & 75 \\
\hline & oceans & 50 & 1) & 10 & 0 & 40 & 50 & 20 & 25 & 50 & 25 \\
\hline & biomass burning & 700 & 1) & 702 & 508 & 507 & 700 & 555 & 507 & 700 & 508 \\
\hline & fossil fuel & 653 & 1) & 300 & 471 & 470 & 650 & 548 & 470 & 650 & 471 \\
\hline & total & 1553 & 1929 & 1168 & 979 & 1147 & 1550 & 1123 & 1077 & 1550 & 1079 \\
\hline \multirow{7}{*}{$\begin{array}{l}\text { NMHC } \\
\operatorname{Tg}(\mathrm{C}) / \mathrm{yr}\end{array}$} & isoprene & 220 & - & 406 & 400 & 450 & 250 & 403 & 507 & 220 & 502 \\
\hline & terpene & - & - & 126 & 100 & - & 0 & 131 & - & 127 & \\
\hline & acetone & - & - & 31 & 23 & - & 30 & 47.3 & 14.3 & 30 & - \\
\hline & fossil fuel & 167 & - & 77 & 91 & 116 & 25 & 77 & 94 & 161 & 96 \\
\hline & biomass burning & 34 & - & 28 & 24 & 31.2 & 10 & 92 & 24 & 33 & 26 \\
\hline & methanol & - & - & 114 & - & - & - & 120 & - & - & \\
\hline & total & & - & 782 & 638 & 597 & 315 & 870 & 639 & 571 & 624 \\
\hline \multicolumn{2}{|l|}{$\mathrm{CH}_{4}$} & 1760 & 1760 & 1750 & 1740 & 1750 & 1760 & 1760 & 1760 & 1745 & 1760 \\
\hline \multicolumn{2}{|l|}{$\mathrm{N}_{2} \mathrm{O}$} & 316 & 316 & 316 & 300 & 291 & - & 315 & - & 315 & 316 \\
\hline \multirow[t]{2}{*}{$\mathrm{CO}_{2}$} & & 369 & 376 & 368 & 350 & 345 & 370 & 367 & - & - & \\
\hline & & $(2 / 8)$ & $(200)$ & $(280)$ & - & $(280)$ & $(200)$ & $(280)$ & - & - & \\
\hline
\end{tabular}

${ }^{1)}$ Only total emission numbers are available.

For this study it was decided that all models use their own emission inventories for the year 2000 simulations (see Table 2), as these inventories are well-tested for each model to simulate present-day atmospheric composition and are used in other publications of the respective model groups in the scientific literature. Year 2000 concentrations of $\mathrm{N}_{2} \mathrm{O}, \mathrm{CH}_{4}$, and $\mathrm{CO}_{2}$ were chosen by the modelers. For the 1850 simulations, all anthropogenic emissions of $\mathrm{NO}_{\mathrm{x}}, \mathrm{CH}_{4}, \mathrm{CO}$, and NMHCs were switched off. Biomass burning emissions were reduced by $90 \%$, a common assumption also used in earlier experiments (Mickley et al., 1999; Shindell et al., 2003; Wong et al., 2004). $\mathrm{CH}_{4}$ and $\mathrm{N}_{2} \mathrm{O}$ were set to values of $791.6 \mathrm{ppbv}$ and $273.8 \mathrm{ppbv}$, respectively, while $\mathrm{CO}_{2}$ levels were chosen by the modelers (see Table 2 ). In all models that include chlorine and bromine chemistry, tropospheric mixing ratios of CFCs, HCFCs, and halons were taken from WMO (2003) for the 2000 simulations and set to zero in the preindustrial runs. $\mathrm{CH}_{3} \mathrm{Cl}$ and $\mathrm{CH}_{3} \mathrm{Br}$ were set to 550 and $6 \mathrm{pptv}$, respectively, in both the 2000 and 1850 simulations. An exception is ULAQ, which used $9.3 \mathrm{pptv}$ for $\mathrm{CH}_{3} \mathrm{Br}$ in the year 2000 simulation.
Sea surface temperatures (SSTs) to be used in the CCMs were taken from prescribed data. ULAQ used a 1960-1970 SST average from Hadley Centre data for the 1850 simulation subtracting $0.3 \mathrm{~K}$ everywhere. For the year 2000 climate, a 1960-2020 SST average from Hadley Center data was used. The DLR_E39C model applied 10-year averages from the MPI-Hamburg coupled ocean-atmosphere general circulation model (ECHAM5-OM) simulations. NCAR applied data from Parallel Climate Model simulations described by Washington et al. (2000), whereas LMDzINCA used SSTs based on Rayner et al. (1996). STOCHEM_HadGEM1 used AMIP-II datasets for the present day climate, while for the preindustrial simulation the model applied data from a long term integration of the Hadley Centre HadCM3 coupled atmosphere-ocean climate model. Also UM_CAM applied data from a Hadley Centre coupled ocean-atmosphere general circulation model simulation for the pre-industrial run (C. E. Johnson, private communication), while the data for the year 2000 simulation was taken from a model simulation similar to that of Cox et al. (2000), prescribing the level of atmospheric $\mathrm{CO}_{2}$ according to the IS92a scenario (Pepper et 
Table 3. List of scenarios.

\begin{tabular}{llll}
\hline Number & Climate & $\mathrm{Cl} / \mathrm{Br}$ & Ozone precursors \\
\hline 1 & preindustrial & preindustrial & preindustrial \\
$1 \mathrm{a}$ & present & preindustrial & present \\
$1 \mathrm{~b}$ & present & present & preindustrial \\
$1 \mathrm{c}$ & present & preindustrial & preindustrial \\
$1 \mathrm{~d}$ & preindustrial & present & preindustrial \\
2 & present & present & present \\
$3^{1)}$ & future & future & future \\
\hline
\end{tabular}

1) Scenario 3 was defined for a year 2100 time slice simulation. This experiment, including several sub-scenarios, has been accomplished during this ACCENT study, but will be analyzed and presented elsewhere.

al., 1992). Finally, CHASER used HadSST data for its preindustrial and present runs.

With respect to stratospheric change since 1850 , the models can be divided into four groups related to the different model set-ups described in the previous section. Models with detailed stratospheric chemistry (ULAQ, DLR_E39C, NCAR_MACCM, and UIO_CTM2) let the stratosphere respond freely to changing ozone precursors and ozone depleting substances. Simplified calculations were used in STOCHEM_HadGEM1 and CHASER (based on the method of Randel and Wu, 1999) and FRSCG (linearized ozone based on McLinden et al., 2000). UM_CAM, STOCHEM_HadAM3, and LMDzINCA did not calculate stratospheric change explicitly.

The scenarios defined for this study are listed in Table 3 . The year 2000 simulation is labeled "scenario 2". A variety of scenarios was defined for 1850 in order to distinguish between contributions from changes in ozone precursors, ozone depleting agents, and climate. Scenario 1 aims at modeling the 1850 atmosphere as closely as possible, taking into account couplings between atmospheric chemistry and climate, both of which are intended to correspond to preindustrial conditions. By contrast, scenarios $1 \mathrm{a}, 1 \mathrm{~b}$, and $1 \mathrm{c}$ use present climate. 1c uses preindustrial emissions, while scenarios $1 \mathrm{a}$ and $1 \mathrm{~b}$ use, respectively, only preindustrial $\mathrm{Cl} / \mathrm{Br}$ levels or only preindustrial ozone precursor levels. The difference " 2 minus $1 c$ " thus represents the chemical change due to increases in anthropogenic emissions, while the difference " 2 minus 1" includes both chemical change and climate change. The differences " 2 minus $1 \mathrm{a}$ " and " 2 minus $1 b$ " focus on the isolated effects of changes in ozone depleting substances and changes in ozone precursors, respectively. Scenario $1 \mathrm{~d}$ was defined for CCMs that do not account for changes in stratospheric chemistry. It assumes preindustrial climate and ozone precursor emissions, but does not consider changes in halogen loading.

Some of the models were able to perform only subsets of the defined scenarios. In particular, the CTMs could not perform scenario 1 since they do not account for couplings between chemistry and climate. Six out of the seven CCMs models did a pre-industrial climate simulation; five among them scenario 1 and one (UM_CAM) scenario $1 \mathrm{~d}$, as this model calculates changes in tropospheric chemistry only. Models without stratospheric chemistry had to simulate scenario $1 \mathrm{~b}$ instead of 1c (LMDzINCA, UM_CAM, STOCHEM_HadAM3). Although the CHASER and STOCHEM_HadGEM1 models do not have comprehensive stratospheric chemistry schemes they could perform scenario $1 \mathrm{c}$, since their methods of calculating stratospheric change take into account changes in chlorine and bromine.

During the integrations the CTMs used the same meteorology repeatedly (year 2000) and applied a sufficient integration length to reach stable results, while CCMs have performed a multi-year integration with sufficient spin-up and reported means from 5 to 10 years of simulation (excluding spin-up) representing a climatology for the year to simulate. An exception is UM_CAM, which has reported data for a single year following a sufficient spin-up time. All models have reported ozone changes from the surface up to $30 \mathrm{~km}$, except LMDzINCA, STOCHEM_HadGEM1, and STOCHEM_HadAM3, which have submitted results up to $20 \mathrm{~km}, 20 \mathrm{~km}$, and $16 \mathrm{~km}$, respectively, related to their lower model lids.

\subsection{Ozone change since preindustrial times}

\subsubsection{The effect of changes in chemistry}

Figure 2 shows the annually averaged zonal-mean ozone change since preindustrial times, accounting for chemical change only. This effect is represented by the difference "scenario 2 minus scenario 1c". It has to be noted that some of the models do not include stratospheric chemistry and thus could not integrate scenario 1c. For these models the difference " 2 minus $1 b$ " is shown, which corresponds to " 2 minus $1 \mathrm{c}$ " without accounting for changes in stratospheric chemistry. Ozone increases are seen throughout the troposphere, except at high southern latitudes, where some models calculate decreases in ozone in the upper troposphere. In low latitudes the ozone increase extends to very high altitudes, which is probably connected with convective upward transport of enhanced tropospheric ozone and ozone precursors. The calculations show that there are differences between the models as to the spatial variation of ozone increase and to its peak magnitude. However, common to all models is a pronounced near-surface increase in ozone in mid- to high northern latitudes, reflecting the location of the main anthropogenic emission sources. There is some disagreement regarding the altitude and the magnitude of the maximum ozone change, ranging from $72 \%$ in the lower troposphere at about 60 degrees North (DLR_E39C) to $176 \%$ in the free troposphere near the equator (UM_CAM). Ozone depletion, especially in the southern lower stratosphere is captured by 

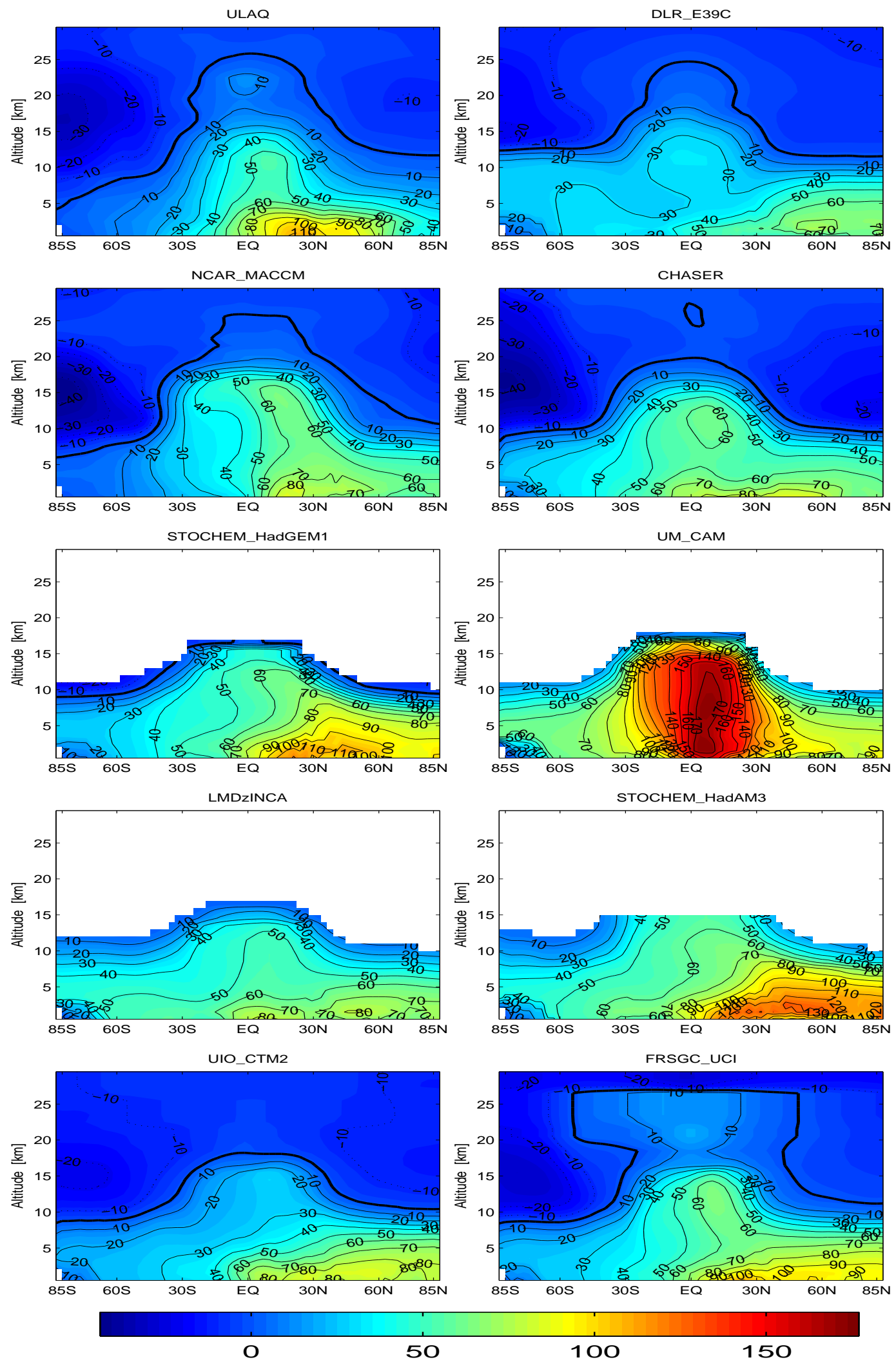

Fig. 2. Annually averaged zonal-mean ozone change (\%) between 1850 and 2000 when taking into account chemical change only (" 2 minus 1c"). For LMDzINCA, UM_CAM, and STOCHEM_HadAM3 "2 minus 1b" is shown. The stratosphere (taken as ozone $>150$ ppbv in year 2000) is masked for the models that do not calculate stratospheric chemistry explicitly. 

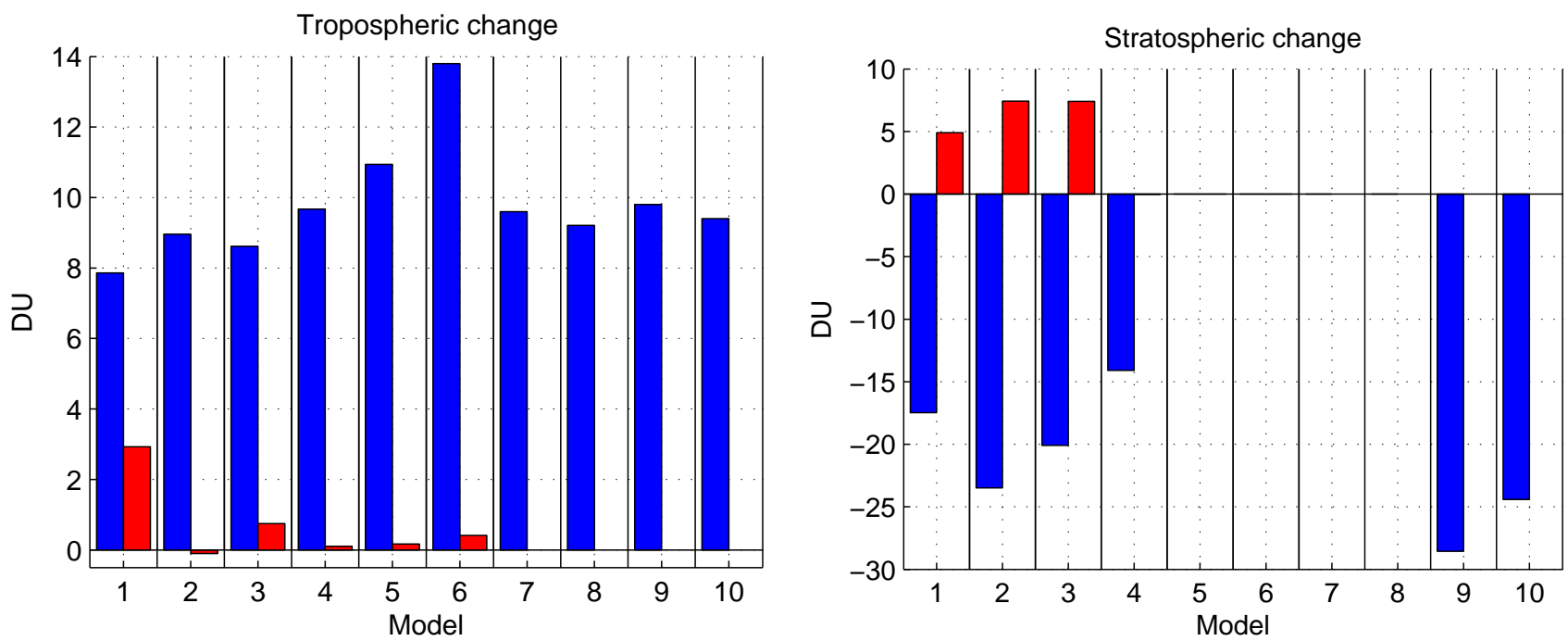

Fig. 3. Change (DU) in the annual-mean (a) tropospheric ozone column and (b) stratospheric ozone column up to $30 \mathrm{~km}$ between 1850 and 2000. Blue bars: "2 minus 1c", reflecting chemical change. Red bars: "1c minus 1", reflecting climate change only. Model numbering as in Table 1. "2 minus $1 b$ " is shown instead of " 2 minus $1 c$ " for LMDzINCA, UM_CAM, and STOCHEM_HadAM3. "1b minus $1 \mathrm{~d}$ " is shown instead of " 1 c minus 1 " for UM_CAM. Stratospheric change is shown only for the models that calculate stratospheric chemistry explicitly. The tropopause level in this analysis is based on the NCEP year 2000 reanalysis.

all models with stratospheric chemistry, although the magnitude of the decrease varies among the models. Qualitatively the stratospheric ozone change agrees well with observed changes (IPCC, 2001; WMO, 2003), although disagreement exists concerning the magnitude and the exact location. For instance, the ULAQ model yields maximum Antarctic ozone depletion at higher altitudes than the other models, while the DLRE39C and UIO_CTM2 models seem to underestimate ozone depletion in the Antarctic lower stratosphere compared to what has been observed.

The calculated change of ozone precursors (not shown) explains in part the differences in modeled ozone change. For example, the maximum annually averaged zonal-mean increase in CO ranges from $10 \mathrm{ppbv}$ in DLR_E39C to over $90 \mathrm{ppbv}$ in the NCAR_MACCM, STOCHEM_HadGEM1, and UM_CAM models. The location of the maximum increase is within the first $3 \mathrm{~km}$ from the surface in mid to high northern latitudes, with additional, but smaller, local maxima in some of the models; ULAQ and CHASER yield an additional local maximum in the upper tropical troposphere, while STOCHEM_HadGEM1, STOCHEM_HadAM3, and UIO_CTM2 calculate local maxima in the lower tropical troposphere. These differences may be connected to different convective transport and will affect chemical ozone production as well. Tropospheric $\mathrm{NO}_{\mathrm{x}}$ increases are largest at the surface in mid-northern latitudes in all models, amounting to several hundred pptv, and then decreasing with height. The locations of the surface maxima agree very well among the models, while their magnitudes range from about 300 pptv in the NCAR_MACCM model to 900 pptv in the
STOCHEM_HadGEM1 model, zonally and annually averaged. The models with stratospheric chemistry calculate a pronounced increase in $\mathrm{NO}_{\mathrm{x}}$ exceeding $1 \mathrm{ppbv}$ in the upper region of the domain between 25 and $30 \mathrm{~km}$. This is related primarily to the increase in $\mathrm{N}_{2} \mathrm{O}$, which is the most important source of $\mathrm{NO}_{\mathrm{x}}$ in this altitude range.

The ozone column changes to be discussed in this section are listed in Table 4. For these calculations the same tropopause definition is used for each model. It is based on NCEP reanalysis data and is also applied in the radiative forcing calculations to be discussed in Sect. 3 .

Figure 3 shows the increase in the global annual-mean ozone column calculated for the troposphere and the lower stratosphere separately, based on the values given in Table 4 . When taking into account chemical change only and regarding tropospheric ozone column increase (blue bars in Fig. 3a) the ten models agree rather well with a mean increase of $9.8 \mathrm{DU}$ and a standard deviation of 1.6 DU. The relatively large ozone increase in the UM_CAM model revealed in Fig. 2 is reflected in the tropospheric ozone column as well, with an increase of almost 14 DU. Horizontal maps of tropospheric column change (not shown) reveal an increase throughout the Northern Hemisphere, and in low and mid latitudes of the Southern Hemisphere. In high Southern latitudes, most models show regional decreases, in two of models even extending over all longitudes (ULAQ and NCAR_MACCM). Such decreases are probably a result of reduced downward flux from the stratosphere following the stratospheric ozone depletion. The absence of stratospheric chemistry change, and thus the absence of the reduction of 
Table 4. Annually averaged total ozone change for the differences " 2 minus 1" (effect of both chemical and climate change), " 2 minus $1 c$ " (effect of chemical change only), and " 2 minus 1a" (effect of chemical change in the stratosphere only). For LMDzINCA, UM_CAM, and STOCHEM_HadAM3 " 2 minus $1 b$ " is shown instead of " 2 minus $1 c$ ", since these models do not include stratospheric chemistry schemes. Related to model setup, not all the models could perform all experiments.

\begin{tabular}{lcccccc}
\hline & \multicolumn{2}{c}{ "2 minus 1" } & \multicolumn{2}{c}{ "2 minus 1c/1b" } & \multicolumn{2}{c}{ "2 minus 1a" } \\
& DU T & DU S & DU T & DU S & DU T & DU S \\
\hline ULAQ & 10.8 & -12.6 & 7.9 & -17.5 & -2.6 & -18.3 \\
DLR_E39C & 8.9 & -16.1 & 9.0 & -23.5 & -2.1 & -17.9 \\
NCAR_MACCM & 9.4 & -12.7 & 8.6 & -20.1 & & \\
CHASER & 9.8 & -14.1 & 9.7 & -14.1 & -1.2 & -14.8 \\
STOCHEM_HadGEM1 & 11.1 & & 10.9 & & & \\
UM_CAM & 14.2 & & 13.8 & & & \\
LMDzINCA & & & 9.6 & & & \\
STOCHEM_HadAM3 & & & 9.2 & & & \\
UIO_CTM2 & & & 9.8 & -28.6 & & \\
FRSGC_UCI & & & 9.4 & -24.4 & 2.2 & -25.4 \\
\hline
\end{tabular}

downward ozone flux from the stratosphere in the UM_CAM model may contribute to the relatively high tropospheric increase in this model.

All models with stratospheric chemistry calculate a significant reduction in the stratospheric ozone burden. Most models group around a stratospheric ozone reduction of $20 \mathrm{DU}$ between the tropopause and $30 \mathrm{~km}$, which seems to be reasonable, taking into account that the assumed 1850 stratospheric ozone is similar to ozone levels in the 1970s, and the ozone column decrease between 1980 and 2000 observed by ozonesondes and satellites between 10 and $30 \mathrm{~km}$ is near 20 DU in northern mid-latitudes (WMO, 2003). The global mean value will be slightly higher due to the relatively strong ozone depletion in high latitudes. In low latitudes no significant stratospheric ozone column reduction has been observed (WMO, 2003).

Four models have integrated scenario $1 \mathrm{a}$ with present climate and ozone precursors, but with pre-industrial chlorine and bromine levels. By comparing the differences " 2 minus 1c" and "2 minus 1a", listed in Table 4, we can estimate the effect of changes in tropospheric chemistry separately. In all models the difference " 2 minus $1 \mathrm{c}$ " yields a much larger tropospheric ozone increase than " 2 minus $1 \mathrm{a}$ ". For example in the ULAQ model the tropospheric column reduction of $-2.6 \mathrm{DU}$ ("2 minus 1a") reflects the influence of stratospheric ozone depletion on tropospheric ozone. By contrast, the difference " 2 minus $1 \mathrm{c}$ " yields a tropospheric column enhancement of 7.9 DU, related to the increase in ozone precursors (which is not included in the difference " 2 minus 1a"). Qualitatively the results of the other three models allow the same conclusions, although the magnitude of the effect varies. In the ULAQ model the stratospheric reduction amounts to -18.3 DU for " 2 minus 1a" and to only $-17.5 \mathrm{DU}$ for " 2 minus $1 \mathrm{c}$ ", probably reflecting the influence of the ozone precursor increase, which is included in

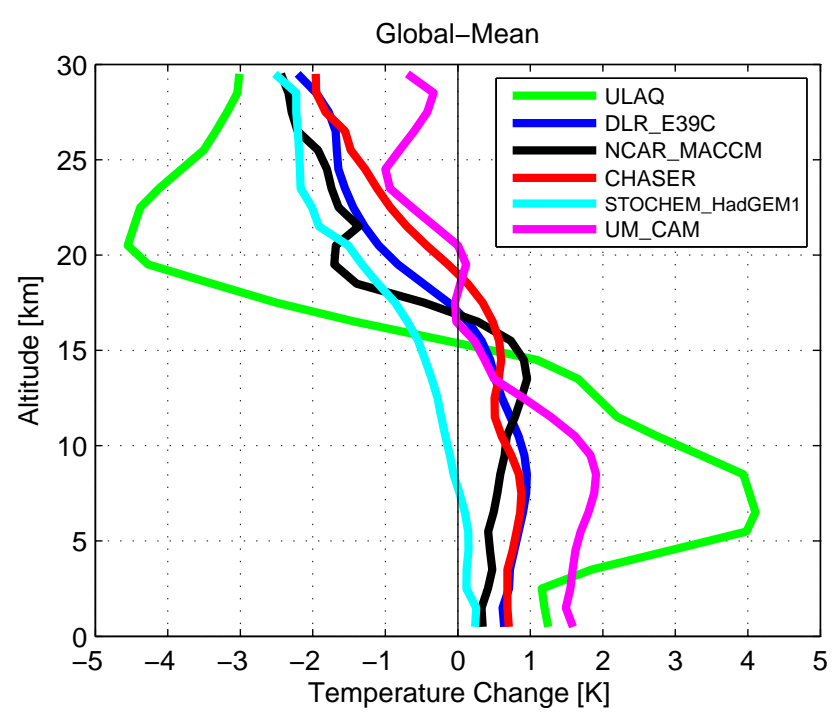

Fig. 4. Annually and globally averaged zonal-mean temperature change $(\mathrm{K})$ between 1850 and 2000 as represented by the difference "2 minus 1". For UM_CAM " 2 minus $1 d$ " is shown.

difference "2 minus 1c" only. Also in the CHASER and RFSGC_UCI models the stratospheric ozone reduction appears to get slightly less severe when taking into account the ozone precursor increase. An exception is the DLR_E39C model which yields a larger stratospheric ozone burden in scenario $1 \mathrm{c}$ than in $1 \mathrm{a}$, the difference " 2 minus $1 \mathrm{c}$ " thus being more negative than " 2 minus $1 \mathrm{a}$ ". One possible reason might be that the $\mathrm{NO}_{\mathrm{x}}$ and methane increase leads to $\mathrm{NO}_{\mathrm{x}}{ }^{-}$ and $\mathrm{OH}$-catalyzed destruction in the stratosphere, which is not compensated by the transport of the relatively low tropospheric ozone increase in DLR_E39C into the lower stratosphere. 

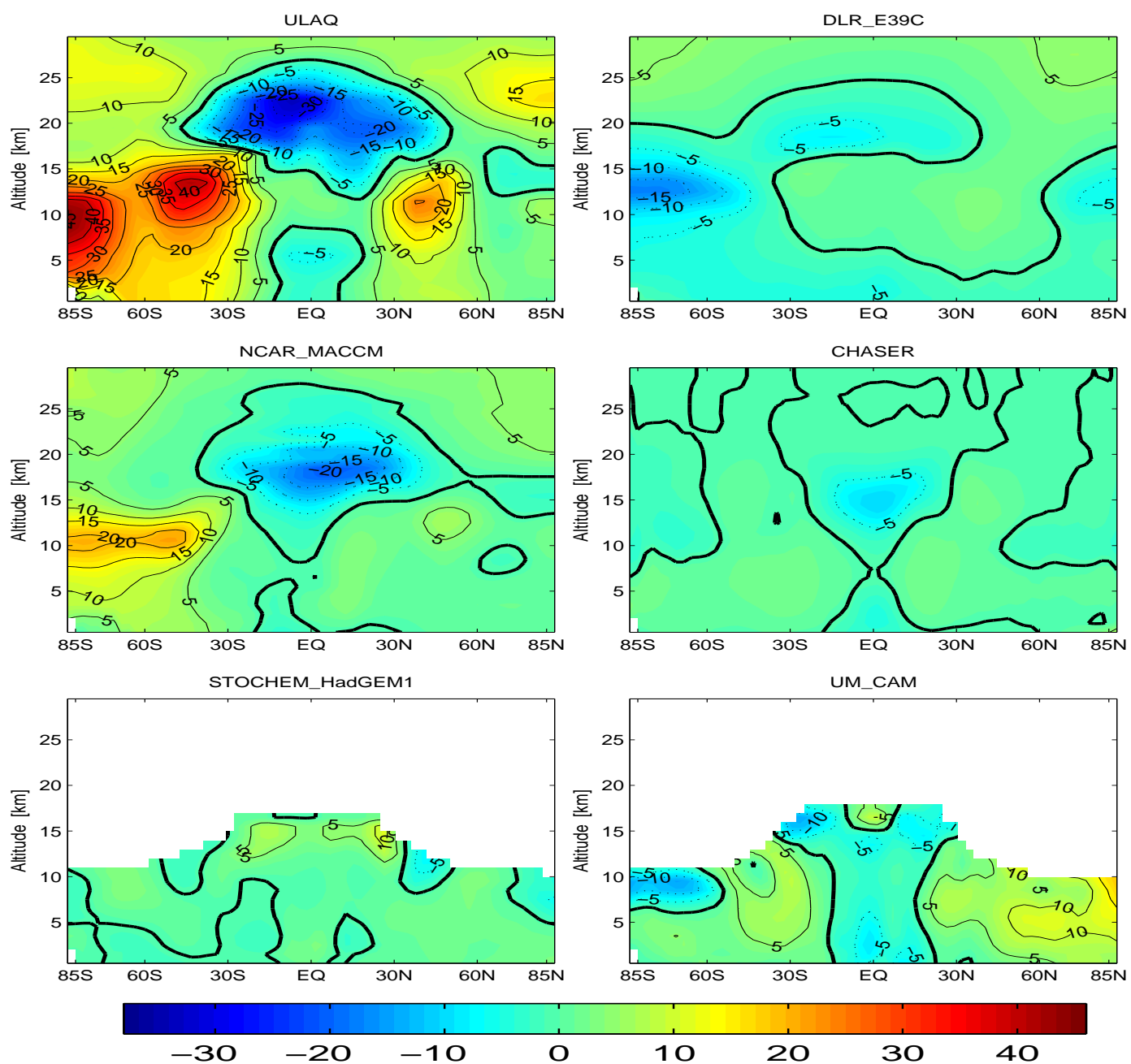

Fig. 5. Annually averaged zonal-mean ozone change (\%) between 1850 and 2000 due to climate change only ("1c minus 1 "). For UM_CAM " $1 \mathrm{~b}$ minus $1 \mathrm{~d}$ " is shown since the model did not run simulations " $1 \mathrm{c}$ " and " 1 ". The stratosphere (taken as ozone $>150$ ppbv in year 2000 ) is masked for the models that do not calculate stratospheric chemistry explicitly.

\subsubsection{The effect of changes in climate}

Interactions between climate and the chemical composition of the atmosphere are manifold and act in both directions. Changes in well-mixed greenhouse gases and ozone have direct effects on radiative transfer, and thereby on temperature and circulation. Atmospheric temperatures and circulation, in turn, affect humidity, precipitation patterns, chemical reaction rates, stratosphere-troposphere exchange (STE), boundary layer ventilation, deposition velocities, etc. These processes influence atmospheric chemistry and thus ozone and other chemically active greenhouse gases.

From radiative transfer considerations, increases in wellmixed greenhouse gases and ozone are assumed to lead to tropospheric warming, while in the stratosphere, increases in well-mixed greenhouse gases and the reduction of ozone both have a cooling effect, as the increase in greenhouse gases leads to increased emissivity of the stratosphere, and the ozone loss leads to a decrease in solar absorption. Consistent with these considerations, all models calculate a general cooling of the stratosphere and a warming of the troposphere since preindustrial times. The annually averaged global-mean temperature increase in the surface layer amounts to $1.25 \mathrm{~K}$ (ULAQ), 0.62 K (DLR_E39C), 0.36 K (NCAR_MACCM), $0.21 \mathrm{~K}$ (CHASER), $1.59 \mathrm{~K}$ (STOCHEM_HadGEM1), and $0.70 \mathrm{~K}$ (UM_CAM), which is in reasonable agreement with the observed value of $0.6 \mathrm{~K}$ (IPCC, 2003), considering that the models do not include the likely negative forcing due to aerosols. Figure 4 shows the annually averaged globalmean temperature change due to changes in sea surface temperatures and well-mixed greenhouse gases (i.e. " $1 \mathrm{c}$ minus 1 "). Warming is seen in the tropospheric layers, while cooling is confined to the stratosphere. An exception is the STOCHEM_HadGEM1 model, which places the transition 
from warming to cooling clearly below the tropopause region.

Figure 5 displays ozone changes due to changes in climate represented by the difference "1c minus 1" (or "1b minus 1d" for UM_CAM), as modeled by the CCMs. In general, two changes are expected to occur due to climate change in the stratosphere: a) a slow down of gas-phase stratospheric ozone depletion due to temperature reductions, and b) an increased meridional circulation, which is connected to a stronger tropical lifting and therefore leads to an ozone decrease in the tropical lower stratosphere, as was identified by, e.g., Kinne et al. (1992) and Stenke and Grewe (2005). Consistently, the three models with detailed stratospheric chemistry (ULAQ, DLR_E39C, and NCAR_MACCM) and CHASER show increases in stratospheric ozone except in the tropical lower stratosphere, where reductions occur. For example, the DLR_E39C model simulates a 5\% decrease of the tropical ozone destruction at about $24 \mathrm{~km}$ altitude as a direct consequence of the temperature decrease shown in Fig. 4, which leads to enhanced ozone mixing ratios. The model also simulates an increase in the annual mean tropical mass flux through $100 \mathrm{hPa}$ from $15.910^{9} \mathrm{kgs}^{-1}$ to $16.910^{9} \mathrm{kgs}^{-1}$, i.e. a $6 \%$ increase, from 1850 to 2000 . This is mainly compensated by an increased Northern Hemisphere extra-tropical downward mass flux, which increases by $9 \%$. In the ULAQ and NCAR_MACCM models stratospheric ozone depletion in high latitudes becomes less pronounced due to climate change, while in DLR_E39C it becomes more pronounced.

The increase of ozone almost everywhere in the troposphere due to climate change is common to all models. Areas of decreases are confined to the lower tropical troposphere, except in the UM_CAM model where the region of ozone decrease covers the entire troposphere between about $15 \mathrm{~S}$ and $15 \mathrm{~N}$. Relatively small signals from climate change are seen in the CHASER model. As far as the stratosphere of CHASER is concerned this is due to the fact that stratospheric ozone concentrations are relaxed to the same prescribed data in the 1 and $1 \mathrm{c}$ scenarios.

The two feedbacks that were apparent in the study of Stevenson et al. (2005) are increased water vapor, reducing ozone, especially in the remote tropical lower troposphere, and enhanced STE, increasing ozone. Increased water vapor resulting from tropospheric warming results in higher levels of $\mathrm{OH}$ and $\mathrm{HO}_{2}$, which are important ozone depleting agents in the troposphere. Furthermore, the additional $\mathrm{OH}$ increases $\mathrm{HNO}_{3}$ formation and reduces $\mathrm{NO}_{\mathrm{x}}$, an ozone precursor, without taking other climate changes into account (Grewe et al., 2001a). These effects probably lead to the ozone decrease, which is seen in the lower tropical troposphere in most models. The increased STE, which also was identified (see Collins et al., 2003; Zeng and Pyle, 2003; Sudo et al., 2003), may cause the ozone increases seen in the upper troposphere in the three CCMs with detailed stratospheric chemistry. In CHASER this increase is also due to increased lightning production of $\mathrm{NO}_{\mathrm{x}}$.
Comparison with Fig. 2 gives an estimate of the importance of climate change compared to chemical change. However, the spatial distribution of the climate change signal of is determined by a complex combination of changes in transport, temperature, and microphysical processes, and, given the small temperature signal in particular, it is difficult to clearly identify the signal above interannual variations.

The isolated effect of climate change on total ozone is shown for the six models that have done Scenario 1 (or 1d) in Fig. 3 by the red bars. As already suggested by the discussion of zonal-mean ozone change, the effect of climate change on the tropospheric ozone column is positive in all CCMs that have made this calculation, except DLR_E39C, which yields a small reduction. The climate change signal is largely a result of the competing effects of increased humidity and increased STE. The models of the present study appear to be more prone to the increase in STE, and, in the case of some models, to increased $\mathrm{NO}_{\mathrm{x}}$ production from lightning. The inclusion of climate change leads to a slightly smaller stratospheric ozone column reduction in the models, which may add to the positive effect of STE.

\section{Radiative transfer calculations}

The ozone changes discussed in the previous section are used as input for detailed radiative forcing calculations. Sections 3.1 and 3.2 will present and discuss radiative forcing calculations made by the University of Oslo radiative transfer model based on tropospheric and stratospheric ozone change, respectively. In order to allow for an estimate of the uncertainty related to radiative transfer calculations, additional radiative transfer models were invited to do the calculation. Section 3.3 will deal with results from the University of Reading and University of L'Aquila radiative transfer models based on the ozone changes obtained in this study. For comparison, radiative forcing results from a similar study made by Harvard University will be presented.

For radiative forcing we follow the definition of IPCCTAR chapter 6 (Ramaswamy et al., 2001), which includes the stratospheric temperature adjustment. Calculations where the stratospheric temperature adjustment is excluded are explicitly denoted as "instantaneous radiative forcing". The University of Oslo and University of Reading radiative transfer models use their respective model meteorologies for all calculations, so that differences within a set of RF results from the same radiative transfer model are entirely due to differences in the modeled ozone changes.

\subsection{Radiative forcing due to tropospheric ozone change}

The University of Oslo radiative transfer model ("UiORTM") is the same as was used in Berntsen et al. (1997), Myhre et al. (2000), and Gauss et al. (2003). The thermal infrared scheme is an absorptivity/emissivity broad band model 

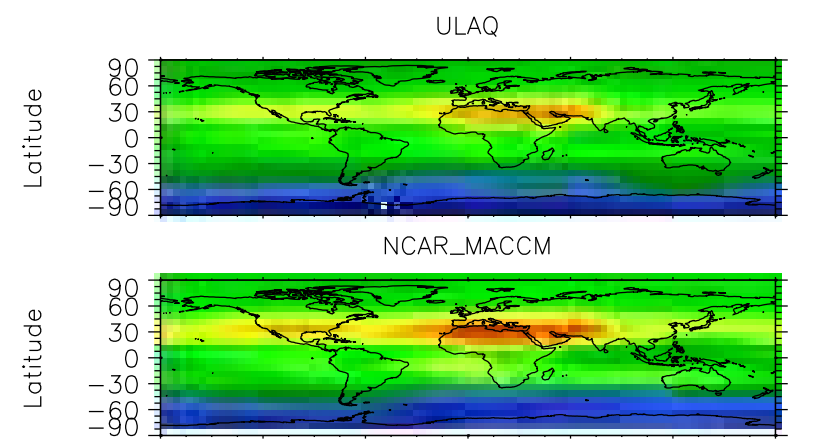

STOCHEM_HadGEM 1

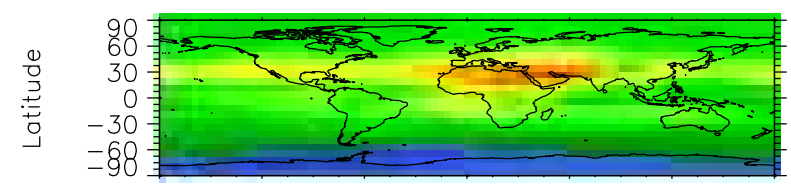

LMDzINCA

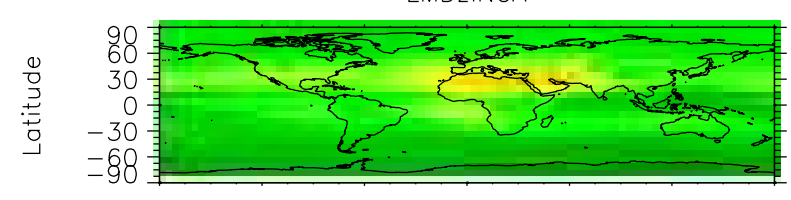

UIO_CTM2
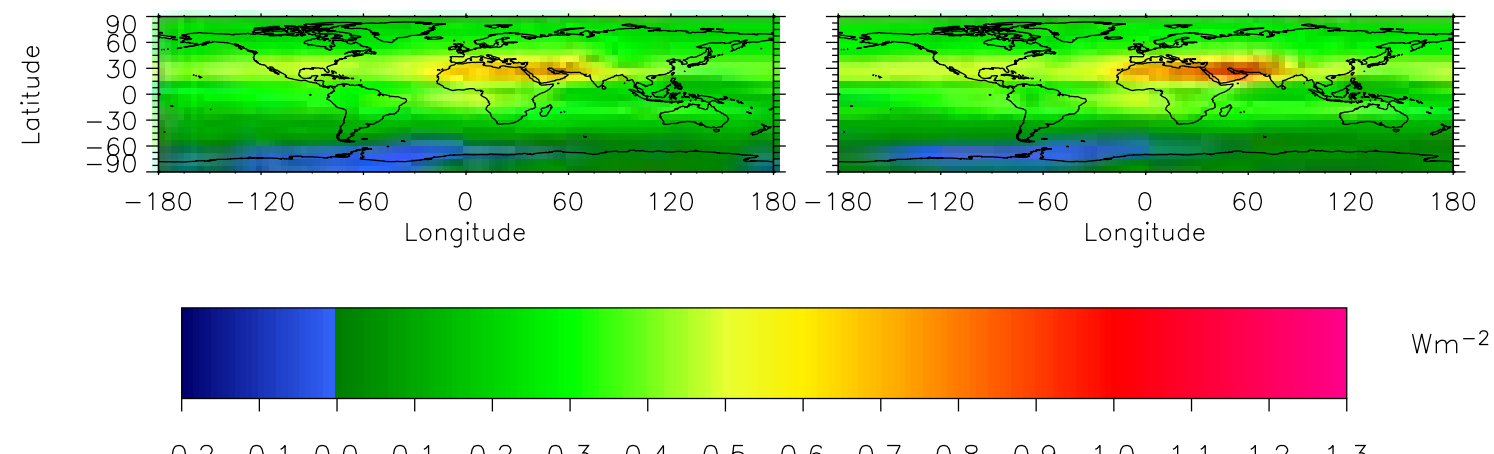

DLR_E39C

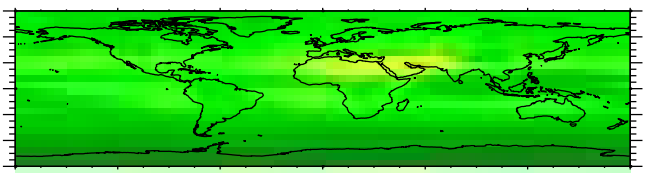

CHASER

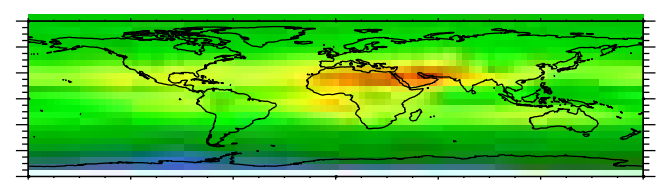

UM_CAM

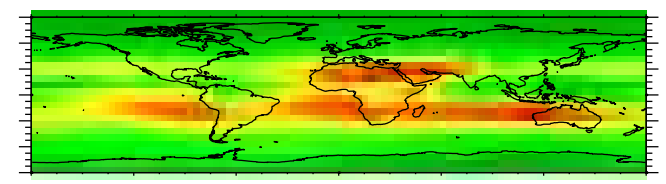

STOCHEM_HadAM3

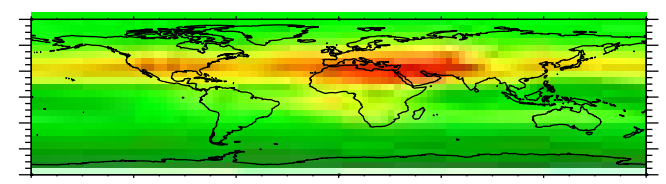

FRSGC_UCI

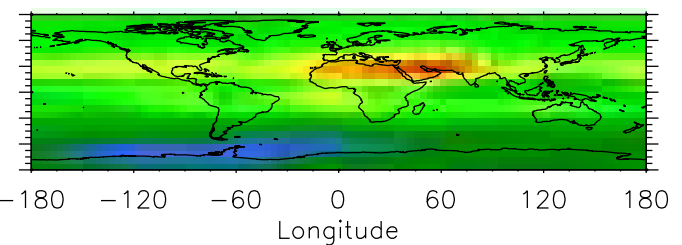

$W m^{-2}$

Fig. 6. Adjusted radiative forcing $\left(\mathrm{Wm}^{-2}\right)$ between 1850 and 2000 due to tropospheric ozone change, taking into account chemical change only (i.e. "2 minus 1c", except LMDzINCA, UM_CAM, and STOCHEM_HadAM3, for which "2 minus 1b" is shown). The radiative forcing calculation is made by the UiO-RTM and the tropopause level is based on the NCEP year 2000 reanalysis.

and the solar scheme is a multi-stream model using the discrete ordinate method (for more details see Myhre et al., 2000). Temperature, water vapor, surface albedo, and cloud data are taken from the European Centre for Medium-range Weather Forecasts (ECMWF). The tropopause level is based on NCEP reanalysis data for the year 2000 and is the same for all radiative forcing calculations in order to allow a convenient standardization between models.

\subsubsection{The effect of changes in chemistry}

Figure 6 shows maps of annual-mean radiative forcing due to changes in tropospheric ozone between 1850 and 2000, when only changes in chemistry are taken into account. Differences can be seen in the magnitude of the forcing, whereas the geographical pattern is rather similar. The radiative forc- ing is almost exclusively positive and a maximum in low latitudes, being a combined effect of ozone increase, higher temperatures, and low solar zenith angles. The longitudinal distribution in the tropics is largely determined by the distribution of ozone change and clouds. Small negative values are seen in high southern latitudes in some of the models. This is due to slight decreases in tropospheric ozone connected with the stratospheric ozone depletion of the last few decades and the resulting reductions in downward transport.

Radiative forcing depends strongly on the vertical distribution of the modeled ozone change. Differences with respect to the height distribution of ozone change will thus add to the differences between the horizontal patterns seen in Fig. 6 and the horizontal distribution of total ozone change (not shown). However, in conclusion it can be said that there 
Table 5. Oslo radiative transfer model results. Annually and globally averaged adjusted radiative forcing $\left(\mathrm{Wm}^{-2}\right)$ since preindustrial times taking into account changes in emissions ("2 minus 1c"). "SW": shortwave radiative forcing, "LW": longwave radiative forcing, "T": tropospheric change, "S": stratospheric change. For LMDzINCA, UM_CAM, and STOCHEM_HadAM3 "2 minus 1b" is shown.

\begin{tabular}{lcccccc}
\hline & SW T & SW S & LW T & LW S & Net T & Net S \\
\hline ULAQ & 0.056 & 0.12 & 0.19 & -0.15 & 0.25 & -0.025 \\
DLR_E39C & 0.069 & 0.20 & 0.19 & -0.19 & 0.26 & 0.009 \\
NCAR_MACCM & 0.070 & 0.14 & 0.23 & -0.15 & 0.30 & -0.009 \\
CHASER & 0.081 & 0.07 & 0.24 & -0.19 & 0.33 & -0.123 \\
STOCHEM_HadGEM1 & 0.091 & & 0.23 & & 0.32 & \\
UM_CAM & 0.102 & & 0.35 & & 0.45 & \\
LMDzINCA & 0.083 & & 0.21 & & 0.29 & \\
STOCHEM_HadAM3 & 0.121 & & 0.27 & & 0.39 & \\
UIO_CTM2 & 0.080 & 0.23 & 0.19 & -0.32 & 0.27 & -0.093 \\
FRSGC_UCI & 0.081 & 0.20 & 0.22 & -0.13 & 0.30 & 0.066 \\
\hline
\end{tabular}

Table 6. As Table 5, but taking into account both chemical and climate change, i.e. " 2 minus 1". For the UM_CAM model " 2 minus $1 \mathrm{~d}$ " is shown.

\begin{tabular}{lcccccc}
\hline & SW T & SW S & LW T & LW S & Net T & Net S \\
\hline ULAQ & 0.079 & 0.13 & 0.27 & -0.19 & 0.35 & -0.059 \\
DLR_E39C & 0.069 & 0.13 & 0.20 & -0.16 & 0.27 & -0.027 \\
NCAR_MACCM & 0.077 & 0.11 & 0.24 & -0.13 & 0.32 & -0.019 \\
CHASER & 0.084 & 0.07 & 0.24 & -0.20 & 0.33 & -0.126 \\
STOCHEM_HadGEM1 & 0.079 & & 0.24 & & 0.33 & \\
UM_CAM & 0.105 & & 0.36 & & 0.46 & \\
\hline
\end{tabular}

is good agreement concerning the radiative forcing due to ozone change in the troposphere.

Global mean net radiative forcing values are listed in Table 5. Globally and annually averaged, the radiative forcing due to tropospheric ozone change ranges from 0.25 to $0.45 \mathrm{Wm}^{-2}$, the mean value and standard deviation being $0.32 \mathrm{Wm}^{-2}$ and $0.06 \mathrm{Wm}^{-2}$, respectively. This value agrees well with the estimate of $0.35 \pm 0.15 \mathrm{Wm}^{-2}$ suggested by IPCC-TAR (Ramaswamy et al., 2001).

\subsubsection{The effect of changes in chemistry and climate com- bined}

Global mean net radiative forcing values for the difference "2 minus 1" (or "2 minus 1d") are listed in Table 6. Globally and annually averaged, the radiative forcing ranges from $0.27 \mathrm{Wm}^{-2}$ to $0.46 \mathrm{Wm}^{-2}$. If only the three CCMs with detailed tropospheric and stratospheric chemistry are taken into account the range is rather narrow, between 0.27 and $0.35 \mathrm{Wm}^{-2}$. For all these models the corresponding increase in the " 2 minus $1 c$ " case was smaller (Table 5), ranging from 0.25 to $0.30 \mathrm{Wm}^{-2}$, i.e. the change in tropospheric ozone due to climate change is noticeably reflected in the radiative forcing. In case of the DLR_E39C model the radiative forcing increases by the inclusion of climate change, although the tropospheric ozone burden is reduced. This is due to the fact that the regions of climate-induced tropospheric ozone increase (Fig. 5) tend to be located at higher altitudes and near the tropopause, where ozone change has a relatively large effect on radiative forcing.

\subsection{Radiative forcing due to stratospheric ozone change}

\subsubsection{The effect of changes in chemistry}

Following a decrease in stratospheric ozone more solar radiation can penetrate to the surface/troposphere system giving a positive SW radiative forcing, while the LW forcing is negative and especially large for ozone changes near the tropopause (Hansen et al., 1997; Forster and Shine, 1997). The balance between the LW and SW forcings is strongly dependent on the altitude of the ozone change, primarily because of the height dependence of the LW. For ozone depletion in the middle stratosphere, due to the infrared opacity of the atmosphere between the mid-stratosphere and the tropopause, the LW forcing will be much weaker than in the lower stratosphere. Figure 7 shows the annual-mean radiative forcing due to changes in stratospheric ozone between 

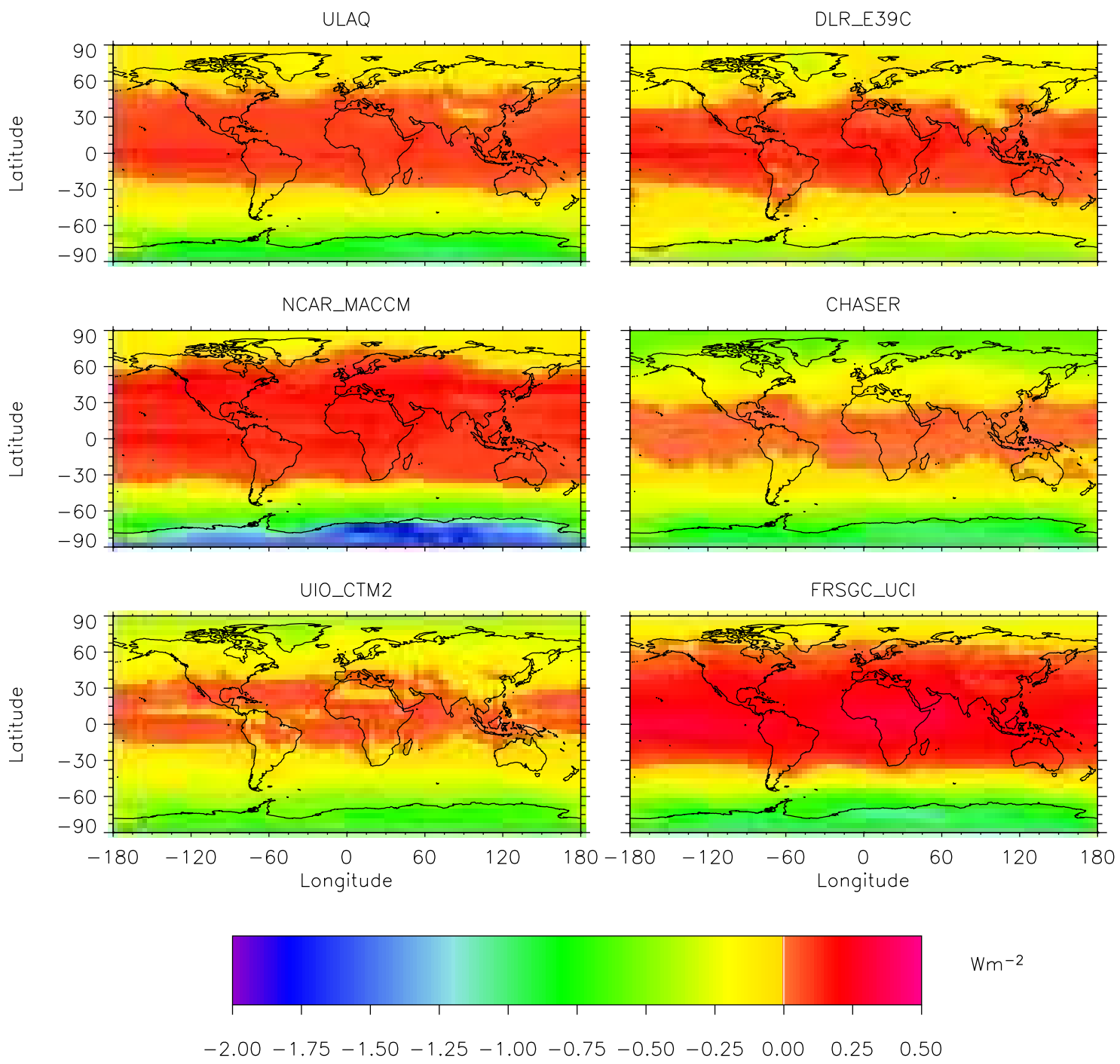

Fig. 7. Adjusted radiative forcing $\left(\mathrm{Wm}^{-2}\right)$ between 1850 and 2000 due to stratospheric ozone change (between the tropopause and $30 \mathrm{~km}$ altitude), taking into account chemical change only ("2 minus 1c"). Results are shown only for models that calculate stratospheric chemistry explicitly. The radiative forcing calculations are made by the UiO-RTM, and the tropopause level is based on the NCEP year 2000 reanalysis.

1850 and 2000. In general, the net forcing from stratospheric ozone change is negative in middle to high latitudes, with magnitudes increasing with latitude. In low latitudes, however, the net radiative forcing can be positive. This is where the ozone depletion is located at rather high altitudes resulting in a weaker (negative) LW signal. Upward transport of the tropospheric ozone increase contributes to this effect by moving the boundary between ozone increase and ozone decrease upwards, thus making the net radiative forcing less negative or even slightly positive in low latitudes. Tropospheric ozone change thus affects global-mean stratospheric radiative forcing, which points to the importance of tropospheric chemistry also in assessments of radiative forcing due to stratospheric ozone change. In general, the models show many similarities, such as the pronounced negative ra- diative forcing in high southern latitudes and the rather low, but positive values in low latitudes.

The global mean net radiative forcings (listed in Table 5) range from small negative to small positive values. There is disagreement regarding the sign of the forcing even among the models with explicit stratospheric chemistry. For those models that tend to simulate ozone depletion at higher altitudes the (positive) SW forcing dominates, while for the other models the (negative) LW forcing dominates. For example, as was seen in Fig. 2, the FRSGC_UCI model yields relatively large ozone depletion in the upper regions of the considered domain, while the UIO_CTM2 model has most of its ozone depletion in the lowermost stratosphere. This is reflected by relatively large positive and negative net forcings for FRSGC_UCI and UIO_CTM2, respectively. However, 

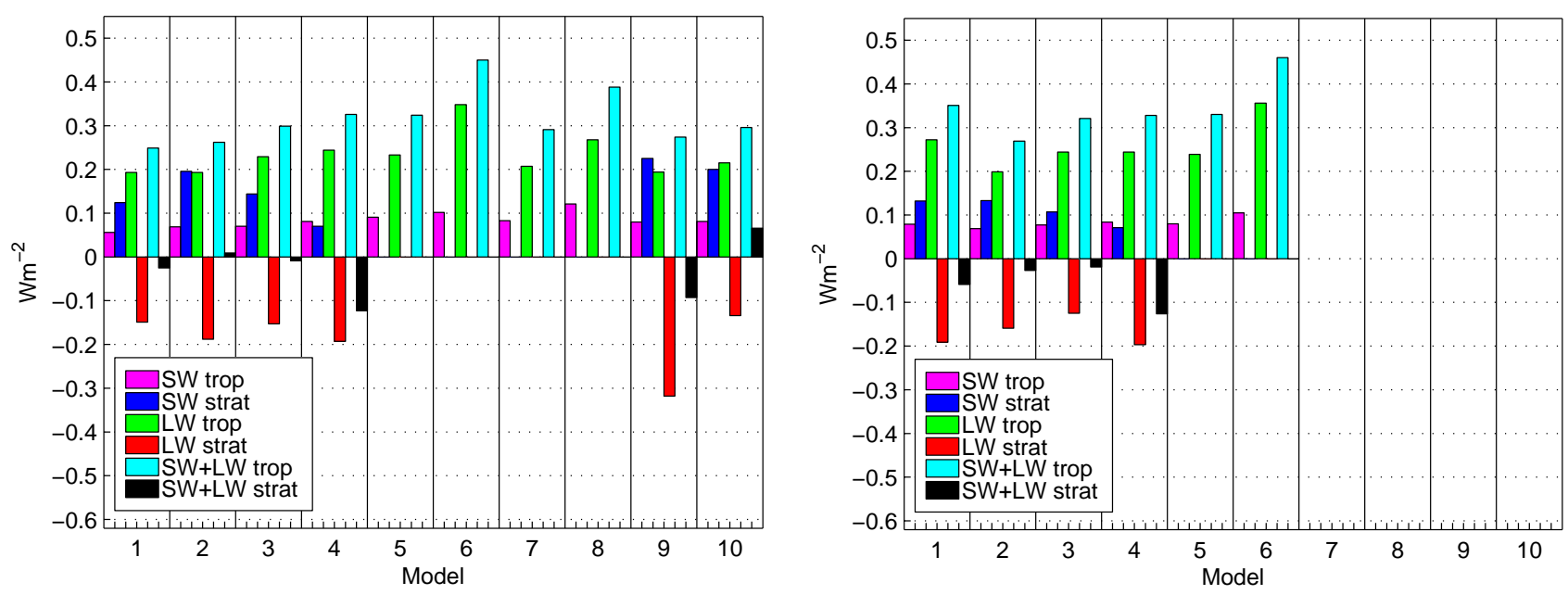

Fig. 8. Components of global-mean adjusted radiative forcing $\left(\mathrm{Wm}^{-2}\right)$ between 1850 and 2000. "SW": shortwave component, "LW": longwave component, "trop": due to tropospheric ozone change, "strat" due to stratospheric change. (a) "2 minus 1c" (for LMDzINCA, UM_CAM, and STOCHEM_HadAM3 "2 minus 1b" is shown), (b) "2 minus 1" (for UM_CAM "2 minus 1d" is shown). Radiative forcing due to stratospheric change is shown only for the models that calculate stratospheric chemistry explicitly. Model numbering as in Table 1. For " 2 minus 1 " only coupled CCMs are shown. The radiative forcing calculations are made by the UiO-RTM, and the tropopause level is based on the NCEP year 2000 reanalysis.

Table 7. Annually and globally averaged adjusted radiative forcing calculated by the ULAQ radiative transfer model (Wm ${ }^{-2}$ ) taking into account chemical change only ("2 minus 1c") and both chemical and climate change ("2 minus 1"). The results are based on ozone changes calculated by the ULAQ model in its native grid extending up to $71 \mathrm{~km}$ altitude. When comparing with Tables 4 and 5 it has to be noted that the results presented in Table 6 include the height range between $30 \mathrm{~km}$ and $71 \mathrm{~km}$ and that the tropopause used by ULAQ differs slightly from that used by the UiO-RTM.

\begin{tabular}{lcccccccr}
\hline & DU T & DU S & SW T & SW S & LW T & LW S & Net T & Net S \\
\hline ULAQ "2 minus 1c" & 8.2 & -20.8 & 0.08 & 0.13 & 0.26 & -0.14 & 0.34 & -0.01 \\
ULAQ "2 minus 1" & 9.7 & -14.2 & 0.10 & 0.14 & 0.29 & -0.15 & 0.39 & -0.01 \\
\hline
\end{tabular}

the positive net stratospheric radiative forcing seen in some models is primarily connected with the pronounced ozone increases in the lower tropical stratosphere of these models.

\subsubsection{The effect of changes in chemistry and climate com- bined}

When taking into account both chemical and climate change the annually averaged global-mean radiative forcing due to changes in stratospheric ozone is negative in all models, varying from -0.019 to $\mathrm{Wm}^{-2}$ to $-0.126 \mathrm{Wm}^{-2}$ among the four models that have done scenario 1 including changes in stratospheric chemistry (see Table 6). The isolated effect of climate change is to reduce the radiative forcing due to stratospheric ozone change. The reason for this is the vertical distribution of ozone change brought about by climate change (see Fig. 5) and the strong altitude dependence of the LW forcing. Ozone increase is seen primarily at high altitudes (middle stratosphere) where the resulting (positive) LW forcing is small, while ozone decrease is modeled at lower altitudes (lower tropical stratosphere), where the resulting (negative) LW forcing is large. The net effect of these changes is thus to reduce the net radiative forcing.

The radiative forcing results calculated by the UiO-RTM and discussed in this and the previous section are summarized as global-mean values in Fig. 8. Both the LW and SW tropospheric forcings are positive, consistent with the tropospheric ozone column increase calculated by all models. The LW and SW forcings connected with the stratospheric ozone column reduction have opposite signs. For some models the negative LW contribution dominates, while in other models the positive SW contribution is larger. While the net tropospheric forcing (light blue bars) is always positive, there is thus disagreement regarding the sign of the net stratospheric forcing. As the comparison between Figs. 8a and b reveals, the inclusion of climate change leads to a general increase in 
Table 8. Annually and globally averaged adjusted radiative forcing calculated by the UiO-RTM and the UoR-RTM (Wm ${ }^{-2}$ ) taking into account chemical change only ("2 minus 1c"). The annual averages in this table are based on January, April, July, and October.

\begin{tabular}{llcccccc}
\hline & & SW T & SW S & LW T & LW S & Net T & Net S \\
\hline \multirow{2}{*}{ ULAQ } & UiO-RTM & 0.056 & 0.125 & 0.192 & -0.151 & 0.248 & -0.026 \\
& UoR-RTM & 0.060 & 0.096 & 0.217 & -0.137 & 0.276 & -0.041 \\
CHASER & UiO-RTM & 0.082 & 0.069 & 0.241 & -0.194 & 0.323 & -0.124 \\
& UoR-RTM & 0.085 & 0.106 & 0.281 & -0.215 & 0.366 & -0.110 \\
\hline
\end{tabular}

the net tropospheric forcing in the CCMs, while a negative contribution is added to the stratospheric radiative forcing.

\subsection{Results from additional radiative transfer models}

Two additional radiative transfer models are applied to allow for a better estimate of the model spread due to different assumptions made in the radiative transfer calculations, such as cloud distributions, temperatures, tropopause heights, and surface albedo.

The University of L'Aquila radiative transfer model ("ULAQ-RTM") is the same as was used in Pitari et al. (2002). The thermal infrared scheme is an absorptivity/emissivity broad band model, explicitly including $\mathrm{CO}_{2}$, $\mathrm{H}_{2} \mathrm{O}, \mathrm{O}_{3}$ and aerosols. For the solar spectrum a $\delta$-Eddington code is used applying solar flux absorption cross-sections and including Rayleigh and Mie scattering effects. Temperature and water vapor vertical profiles are those internally calculated in the ULAQ GCM. The tropopause level is set at the 150 ppbv ozone level from a reference (year 2000) calculation. The ULAQ-RTM is directly coupled to the ULAQ model that did the ozone change calculations discussed in Sect. 2. Results based on this ozone change are shown in Table 7. The net tropospheric forcing amounts to $0.34 \mathrm{Wm}^{-2}$ and $0.39 \mathrm{Wm}^{-2}$ for the differences " 2 minus $1 \mathrm{c}$ " and " $2 \mathrm{mi}$ nus 1", respectively, while the net stratospheric forcing is slightly negative amounting to $-0.01 \mathrm{Wm}^{-2}$ in both cases. It has to be noted that the ULAQ-RTM takes into account ozone change up to an altitude of $71 \mathrm{~km}$, which is the upper boundary of the ULAQ model. Apart from the different meteorological conditions used in the ULAQ-RTM, the additional ozone column reduction between 30 and $71 \mathrm{~km}$ explains in part the different forcings compared to the UiORTM calculations.

The University of Reading radiative transfer model ("UoR-RTM") is a narrow band model (Shine, 1991), which resolves the thermal infrared spectrum in $10 \mathrm{~cm}^{-1}$ bands. For the solar spectrum, a four stream discrete-ordinate model (Stamnes et al., 1998) is used. The water vapor and temperature vertical profiles are taken from the ECMWF Re-analysis dataset (ERA-40) and the cloud and surface albedo data is taken from ISCCP. The tropopause height is defined as the height at which the lapse rate is $2 \mathrm{~K} / \mathrm{km}$ in all the calcula- tions using the UoR-RTM. This radiative transfer model was previously used in Berntsen et al. (1997), and in Forster and Shine (1997). UoR-RTM has calculated adjusted radiative forcing based on the ozone changes calculated by the ULAQ and CHASER model for the months of January, April, July, and October. The results are shown in Table 8 along with the corresponding UiO-RTM results. There is reasonably good agreement between the two radiative transfer models, especially in the tropospheric forcings. In the stratosphere, and for ULAQ in particular, there is some disagreement in the net forcing, which is, however, the sum of the two large LW and SW contributions of opposite sign, which themselves agree rather well. Also, it has to be noted that, related to extrapolation procedures, UiO-RTM took into account ozone changes up to about $42 \mathrm{~km}$ (which is the upper boundary of the ECMWF model layer being used in the UiO-RTM) while the UoR-RTM considered ozone changes only up to $30 \mathrm{~km}$.

Additional calculations of both the ozone change since preindustrial times and the resulting radiative forcing were provided by the Harvard University. The Harvard-GISS model is a version of the general circulation model (GCM) developed at the Goddard Institute for Space Studies (GISS), the GISS-GCM II' (Rind and Lerner, 1996; Rind et al., 1999). The model includes a detailed, on-line chemistry scheme with about 80 chemical species and 400 chemical reactions. Two different model versions were used. In the "standard" model, natural and anthropogenic emissions are largely based on Wang et al. (1998). Monthly mean fluxes of ozone and $\mathrm{NO}_{\mathrm{y}}$ across the model tropopause are specified as in Wang et al. (1998). Like most other chemistry models, the "standard" model overestimates preindustrial ozone concentrations compared to surface observations from the late 1800s. Results from a "tuned" version of the model, in which lightning $\mathrm{NO}_{\mathrm{x}}$ emissions have been reduced and biogenic hydrocarbon emissions have been increased, better matches the surface ozone observations available from the end of the 19th century. For more details see Mickley et al. (1999) and Mickley et al. (2001). The Harvard-GISS radiative transfer model employs the correlated k-distribution method to determine radiative absorption and emission in the longwave and shortwave spectral region (Hansen et al., 1983). Radiative forcing is calculated on-line in the GCM, but does not feed back into the model climate; the present-day and 
preindustrial simulations use exactly the same meteorological fields. In this coarse-grid model, the tropopause is defined as the boundary between the model layers 7 and 8 (about $150 \mathrm{hPa}$ ). Results for the two calculations are shown in Table 9. The adjusted forcing for tropospheric ozone added to the atmosphere since preindustrial times is $0.38 \mathrm{Wm}^{-2}$ in the case of the "standard" simulation. This value agrees well with the calculations presented in Sect. 3.1. A considerably larger total ozone change in the "tuned" model version leads to a larger radiative forcing amounting to $0.68 \mathrm{Wm}^{-2}$.

The comparison of the UiO-RTM results with the ULAQRTM and UoR-RTM results points to some disagreement, which is due to different assumptions on the meteorological conditions and, in the case of ULAQ-RTM the different height range considered in the stratosphere. The radiative forcing calculations made by the Harvard-GISS "standard" model agree rather well with those based on the modeled ozone change obtained in this study. However, the radiative forcing in the Harvard-GISS "tuned" model is considerably larger, pointing to the uncertainty in modeled ozone change since preindustrial times.

\section{Conclusions and outlook}

In this analysis ozone changes in the troposphere and lower stratosphere calculated by seven CCMs and three CTMs for the period 1850-2000 have been used to calculate radiative forcing. The CCMs have calculated both chemical and climate change, while the CTMs have kept the climate fixed at year 2000 conditions. The study shows that, even though state-of-the-art models have been used, the uncertainty in modeling ozone change since the pre-industrial time is still large. However, key findings concerning the global-mean tropospheric ozone change and its resulting radiative forcing are rather robust.

The simulated change of the globally and annually averaged tropospheric ozone column seems to be rather robust and lies within the range of 7.9 DU to $13.8 \mathrm{DU}$, when only chemical change is taken into account. Among the models that calculate chemical change in the stratosphere (all models except STOCHEM_HadGEM1, UM_CAM, and STOCHEM_HadAM3) the range of tropospheric ozone change is even narrower, lying between $7.9 \mathrm{DU}$ to $9.8 \mathrm{DU}$. In the calculations accounting for both chemical and climate change, the tropospheric ozone increase is in the range 8.9 DU to $10.8 \mathrm{DU}$ among the CCMs with detailed tropospheric and stratospheric chemistry. The stratospheric burden is reduced by between 12.6 DU and 16.1 DU in these models. The inclusion of climate change yields larger tropospheric ozone increases in most models, especially in the models with both tropospheric and stratospheric chemistry. This points to a dominance of the positive effect from increased stratosphere-troposphere exchange and possibly increased lightning emissions over the negative effect of in-
Table 9. Annually and globally averaged adjusted radiative forcing calculated by the Harvard GISS-RTM $\left(\mathrm{Wm}^{-2}\right)$ based on ozone changes calculated in two different experiments with the HarvardGISS chemical transport model. Details about the "standard" and "tuned" experiments are given in the text.

\begin{tabular}{lcccc}
\hline & DU T & SW T & LW T & Net T \\
\hline Harvard-GISS standard & 11.8 & 0.11 & 0.27 & 0.38 \\
Harvard-GISS tuned & 19.4 & 0.18 & 0.50 & 0.68 \\
\hline
\end{tabular}

creased humidity in the troposphere. We also note that concerning the separated effect of climate change on modeled ozone change, the results from the CCMs including detailed tropospheric and stratospheric chemistry schemes are rather consistent. These results are in contrast to those from an earlier study (Johnson et al., 1999), which predicted a 10\% decrease in the tropospheric ozone burden due to climate change in a doubled- $\mathrm{CO}_{2}$ atmosphere. In that study, temperatures close to the surface increased by $3.28 \mathrm{~K}$ (or about $2-5$ times the temperature increase calculated here), and the effect of increased water vapor swamped the effect of increased stratosphere-troposphere exchange.

Important sources of disagreement among the models calculating ozone change were already identified in a similar study of Gauss et al. (2003) and include the different meteorological data sets and different transport and chemistry formulations that are applied. This also includes stratospheretroposphere exchange and other transport processes occurring on a sub-grid scale, such as boundary layer mixing and convection, which are represented in quite different ways and greatly affect the vertical profiles of ozone and its precursors.

When taking into account only chemical change, tropospheric ozone column change has led to a radiative forcing of $0.32 \mathrm{Wm}^{-2}$, averaged over the models. The contribution of stratospheric ozone change to radiative forcing is less certain, but globally averaged it is slightly negative in most of the models including stratospheric chemistry. The inclusion of climate change leads to a further increase in radiative forcing due to tropospheric ozone change.

A striking result is that the net (troposphere plus stratosphere) ozone change is of opposite sign to the net (troposphere plus stratosphere) forcing for all models and cases considered here. The net ozone change is negative because of the overwhelming impact of the stratospheric ozone depletion, but the smaller change in the troposphere ozone has a greater impact on the forcing. This appears to reflect the fact that much of the stratospheric loss is away from the vital lower stratospheric region, where the ozone change has its greatest impact on the forcing.

The main uncertainties in the radiative forcing calculations arise from the differences in global-mean ozone column change as simulated by the various CCMs and CTMs. The 
contribution of the radiative forcing uncertainties caused by different meteorological conditions is of secondary importance.

From this study it seems clear that both tropospheric and stratospheric chemistry need to be taken into account, as the tropospheric ozone increase since preindustrial times has moderated lower stratospheric ozone depletion in low latitudes, while stratospheric ozone depletion during the last three decades has influenced tropospheric ozone increase in high latitudes. In this context it will be important to further investigate transport of ozone through the tropopause. In the long run it should become possible to consider radiative forcing from tropospheric and stratospheric changes combined. Also, it is clear from the model results that further model studies will be needed to investigate the contribution from climate change to changes in ozone, both in the troposphere and in the stratosphere, with focus on changes in temperatures, water vapor concentrations, and stratospheric circulation.

Regarding radiative forcing calculations of this type it will be important in the future to clearly distinguish between radiative forcing due to ozone changes resulting from changing emissions and from changing climate, which under certain circumstances should be considered as a climate feedback rather than a contribution to radiative forcing.

Acknowledgements. This study has been supported by the European Commission through ACCENT, a European Network of Excellence within Framework Programme 6.

NCEP Reanalysis data for tropopause pressure was provided by the NOAA-CIRES Climate Diagnostics Center, Boulder, Colorado, USA, from their web site at http://www.cdc.noaa.gov/.

L. K. Gohar and K. P. Shine acknowledge NERC grant NER/L/S/2001/00661.

V. Grewe thanks E. Roeckner from the Max-Planck Institute for Meteorology, Hamburg for providing sea surface temperatures from a coupled ECHAM5/OM simulation and the DKRZ (Deutsches Klimarechenzentrum) for providing computing facilities.

Edited by: V. Fomichev

\section{References}

Berntsen, T. K., Isaksen, I. S. A., Myhre, G., Fuglestvedt, J. S., Stordal, F., Larsen, T. A., Freckleton, R. S., and Shine, K. P.: Effects of anthropogenic emissions on tropospheric ozone and its radiative forcing, J. Geophys. Res., 102, 28 101-28 126, 1997.

Berntsen, T. K. and Isaksen, I. S. A.: Effects of lightning and convection on changes in tropospheric ozone due to $\mathrm{NO}_{\mathrm{X}}$ emissions from aircraft, Tellus, 51B, 766-788, 1999.

Berntsen, T. K., Myhre, G., Stordal, F., and Isaksen, I. S. A.: Time evolution of tropospheric ozone and its radiative forcing, J. Geophys. Res., 105, 8915-8930, 2000.

Bojkov, R. D.: Surface Ozone during the 2nd half of the 19th century, J. Clim. Appl. Meteorol., 25(3), 343-352, 1986.
Boville, B. A.: Middle atmosphere version of CCM2 (MACCM2): Annual cycle and interannual variability, J. Geophys. Res., 100(D5), 9017-9040, 1995.

Carver, G. D., Brown, P. D., and Wild, O.: The ASAD atmospheric chemistry integration package and chemical reaction database, Computer Physics Communications, 105, 197-215, 1997.

Collins, W. J., Stevenson, D. S., Johnson, C. E., and Derwent, R. G.: Tropospheric ozone in a global-scale three-dimensional Lagrangian model and its response to $\mathrm{NO}_{\mathrm{x}}$ emission controls, $\mathrm{J}$. Atmos. Chem., 26, 223-274, 1997.

Collins, W. J., Derwent, R. G, Johnson, C. E., and Stevenson, D. S.: A comparison of two schemes for the convective transport of chemical species in a Lagrangian global chemistry model, Q. J. R. Meteorol. Soc., 128, 991-1009, 2002.

Collins, W. J., Derwent, R. G., Garnier, B., Johnson, C. E., Sanderson, M. G., and Stevenson, D. S.: The effect of stratospheretroposphere exchange on the future tropospheric ozone trend, J. Geophys. Res., 108(D12), 8528, doi:10.1029/2002JD002617, 2003.

Cox, P. M., Betts, R. A., Jones, C. D., Spall, S. A., and Totterdell, I. J.: Amazonian forest dieback under climate-carbon cycle projections for the 21st Century, Nature, 408, 184-187, 2000.

Dameris, M., Grewe, V., Ponater, M., Deckert, R., Eyring, V., Mager, F., Matthes, S., Schnadt, C., Stenke, A., Steil, B., Brühl, C., and Giorgetta, M.: Long-term changes and variability in a transient simulation with a chemistry-climate model employing realistic forcing, Atmos. Chem. Phys., 5, 2121-2145, 2005.

Dufresne, J.-L., Friedlingstein, P., Berthelot, M., Bopp, L., Ciais, P., Fairhead, L., Le Treut, H., and Monfray, P.: On the magnitude of positive feedback between future climate change and the carbon cycle, Geophys. Res. Lett., 29(10), 1405, doi:10.1029/2001GL013777, 2002.

Emori, S., Nozawa, T., Numaguti, A., and Uno, I.: Importance of cumulus parameterization for precipitation simulation over East Asia in June, J. Meteorol. Soc. Japan, 79, 939-947, 2001.

de F. Forster, P. M. and Shine, K. P.: Radiative forcing and temperature trends from stratospheric ozone changes, J. Geophys. Res., 102(D9), 10 841-10 856, doi:10.1029/96JD03510, 1997.

de F. Forster, P. M.: Radiative forcing due to stratospheric ozone changes 1979-1997, using updated trend estimates, J. Geophys. Res., 104(D20), 24395-24 400, doi:10.1029/1999JD900770, 1999.

Fortuin, J. P. F. and Kelder, H.: An ozone climatology based on ozonesonde and satellite measurements, J. Geophys. Res., 103, 31 709-31 734, 1998.

Gauss, M., Myhre, G., Pitari, G., Prather, M. J., Isaksen, I. S. A., Berntsen, T. K., Brasseur, G. P., Dentener, F. J., Derwent, R. G., Hauglustaine, D. A., Horowitz, L. W., Jacob, D. J., Johnson, M., Law, K. S., Mickley, L. J., Müller, J.-F., Plantevin, P.-H., Pyle, J. A., Rogers, H. L., Stevenson, D. S., Sundet, J. K., van Weele, M., and Wild, O.: Radiative forcing in the 21 st century due to ozone changes in the troposphere and the lower stratosphere, J. Geophys. Res., 108(D9), 4292, doi:10.1029/2002JD002624, 2003.

Granier, C. and Shine, K. P.: Climate Effects of Ozone and Halocarbon Changes, Chapter 10, in: Scientific Assessment of Ozone Depletion: 1998, Global Ozone Research and Monitoring Project-Report No. 44, World Meteorological Organization, Geneva, Switzerland, 10.1-10.38, 1999. 
Gregory, D. and Rowntree, P. R.: A mass flux convection scheme with representation of cloud ensemble characteristics and stability dependent closure, Mon. Wea. Rev., 118, 1483-1506, 1990.

Grewe, V., Dameris, M., Hein, R., Sausen, R., and Steil, B.: Future changes of the atmospheric composition and the impact of climate change, Tellus, 53B, 103-121, 2001a.

Grewe, V., Brunner, D., Dameris, M., Grenfell, J. L., Hein, R., Shindell, D., and Staehelin, J.: Origin and variability of upper tropospheric nitrogen oxides and ozone at northern mid-latitudes, Atmos. Environ., 35, 3421-3433, 2001b.

Hack, J. J.: Parameterization of moist convection in the NCAR community climate model (CCM2), J. Geophys. Res., 99, 55515568, 1994.

Hansen, J., Russell, G., Rind, D., Stone, P., Lacis, A., Lebedeff, S., Ruedy, R., and Travis, L.: Efficient three-dimensional models for climate studies: Models I and II, Mon. Wea. Rev., 3, 609-662, 1983.

Hansen, J., Sato, M., and Ruedy, R.: Radiative forcing and climate response, J. Geophys. Res., 102, 6831-6864, 1997.

Hauglustaine, D. A. and Brasseur, G. P.: Evolution of tropospheric ozone under anthropogenic activities and associated radiative forcing of climate, J. Geophys. Res., 106, 32 337-32 360, 2001.

Hauglustaine, D. A., Hourdin, F., Walters, S., Jourdain, L., Filiberti, M.-A., Larmarque, J.-F., and Holland, E. A.: Interactive chemistry in the Laboratoire de Météorologie Dynamique general circulation model: description and background tropospheric chemistry evaluation, J. Geophys. Res., 109, D04314, doi:10.1029/2003JD003957, 2004.

Hein, R., Dameris, M., Schnadt, C., Land, C., Grewe, V., Köhler, I., Ponater, M., Sausen, R., Steil, B., Landgraf, J., and Brühl, C.: Results of an interactively coupled atmospheric chemistrygeneral circulation model: Comparison with observations, Ann. Geophys., 19, 435-457, 2001.

Isaksen, I. S. A., Harris, N. R. P., Penkett, R. G., et al.: Ozoneclimate interactions, Air pollution report no. 81 (EUR 20623), European Commission, Brussels, pp. 143, 2003.

Isaksen I. S. A., Zerefos, C. S., Kourtidis, K., Meleti, C., Dalsoren, S. B., Sundet, J. K., Grini, A., Zanis, P., Balis, D.: Tropospheric ozone changes at unpolluted and semipolluted regions induced by stratospheric ozone changes, J. Geophys. Res., 110, D02302, doi:10.1029/2004JD004618, 2005.

Johnson, C. E., Collins, W. J., Stevenson, D. S., and Derwent, R. G.: Relative roles of climate and emissions changes on future tropospheric oxidant concentrations, J. Geophys. Res., 104, $18631-$ $18645,1999$.

Kiehl, J. T., Schneider, T. L., Portmann, R. W., and Solomon, S.: Climate forcing due to tropospheric and stratospheric ozone, J. Geophys. Res., 104, 31 239-31 254, 1999.

Kinne, S., Toon, O. B., and Prather, M. J.: Buffering of stratospheric circulation by changing amounts of tropical ozone - a Pinatubo case study, Geophys. Res. Lett., 19, 1927-1930, 1992.

Lacis, A. A., Wuebbles, D. J., and Logan, J. A.: Radiative forcing by changes in the vertical distribution of ozone, J. Geophys. Res., 95, 9971-9981, 1990.

Lamarque, J.-F., Hess, P., Emmons, L., Buja, L., Washington, W., and Granier, C.: Tropospheric ozone evolution between 1890 and 1990, J. Geophys. Res., 110, D08304, doi:10.1029/2004JD005537, 2005.

Leonard, B. P., Lock, A. P., and MacVean, M. K.: The NIRVANX scheme applied to one-dimensional advection, Int. J. Numer. Methods Heat Fluid Flow, 5, 341-377, 1995.

Lin, S.-J. and Rood, R. B.: Multidimensional flux-form semiLagrangian transport schemes, Mon. Wea. Rev., 124, 20462070, 1996.

Marenco, A., Gouget, H., Nedelec, P., Pages, J. P., and Karcher, F.: Evidence of a long-term increase in tropospheric ozone from Pic du Midi data series - consequences - positive radiative forcing, J. Geophys. Res., 99(D8), 16 617-16 632, 1994.

McLinden, C. A., Olsen, S., Hannegan, B., Wild, O., Prather, M. J., and Sundet, J.: Stratospheric ozone in 3-D models: A simple chemistry and the cross-tropopause flux, J. Geophys. Res., 105, 14 653-14 665, 2000.

Mickley, L. J., Murti, P. P., Jacob, D. J., Logan, J. A., Rind, D., and Koch, D.: Radiative forcing from tropospheric ozone calculated with a unified chemistry-climate model, J. Geophys. Res., 104, 30 153-30 172, 1999.

Mickley, L. J., Jacob, D. J., and Rind, D.: Uncertainty in preindustrial abundance of tropospheric ozone: implications for radiative forcing calculations, J. Geophys. Res., 106, 3389-3399, 2001.

Müller, J.-F. and Brasseur, G.: IMAGES: A three-dimensional chemical transport model of the global troposphere, J. Geophys. Res., 100, 16445-16490, 1995.

Myhre, G., Karlsdóttir, S., Isaksen, I. S. A., and Stordal, F.: Radiative forcing due to changes in tropospheric ozone in the period 1980 to 1996, J. Geophys. Res., 105, 28 935-28 942, 2000.

Myhre, G., Myhre, A., and Stordal, F.: Historical evolution of radiative forcing of climate, Atmos. Environ., 35, 2361-2373, 2001.

Pepper, W. J., Leggett, J., Swart, R., Wasson, J., Edmonds, J., and Mintzer, I.: Emissions Scenarios for the IPCC, An Update: Assumptions, Methodology, and Results, Support Document for Chapter A3, in: Climate Change 1992: Supplementary Report to the IPCC Scientific Assessment, edited by: Houghton, J. T., Callandar, B. A., and Varney, S. K., Cambridge University Press, Cambridge, 1992.

Pitari, G.: A numerical study of the possible perturbation of stratospheric dynamics due to Pinatubo aerosols - Implications for tracer transport, J. Atmos. Sci., 50, 2443-2461, 1993.

Pitari, G., Grassi, B., and Visconti, G.: Results of a ChemicalTransport Model with Interactive Aerosol Microphysics, edited by: Bojkov, R. D. and Visconti, G., XVIII O3 symp. proc., p. 759, 1997.

Pitari, G., Mancini, E., Rizi, V., and Shindell, D. T.: Impact of future climate and emission changes on stratospheric aerosols and ozone, J. Atmos. Sci., 59, 414-440, 2002.

Prather, M. J.: Numerical advection by conservation of secondorder moments, J. Geophys. Res., 91, 6671-6681, 1986.

Ramaswamy, V., Boucher, O., Haigh, J., Hauglustaine, D., Haywood, J., Myhre, G. Nakajima, T., Shi, G. Y., and Solomon, S.: Radiative Forcing of Climate Change, in: Climate Change 2001: The Scientific Basis, Contribution of Working Group I to the Third Assessment Report of the Intergovernmental Panel on Climate Change (IPCC), edited by: Houghton, J. T., Ding, Y., Griggs, D. J., Noguer, M., van der Linden, P. J., Dai, X., Maskell, K., and Johnson, C. A., Cambridge University Press, Cambridge, United Kingdom and New York, NY, USA, 881 p., 2001.

Randel, W. J. F. and Wu, A.: stratospheric ozone trends data set for global modeling studies, Geophys. Res. Lett., 26(20), 30893092, doi:10.1029/1999GL900615, 1999. 
Rayner, N. A., Horton, E. B., Parker, D. E., Folland, C. K., and Hackett, R. B.: Version 2.2 of the global sea-ice and sea-surface temperature data set, 1903-1994, CRTN 74, Hadley Centre, Met. Office, Bracknell, UK, 1996.

Rind, D. and Lerner, J.: Use of on-line tracers as a diagnostic tool in general circulation model development, 1 , Horizontal and vertical transport in the troposphere, J. Geophys. Res., 101, 12 66712 683, 1996.

Rind, D., Lerner, J., Shah, K., and Suozzo, R.: Use of on-line tracers as a diagnostic tool in general circulation model development, 2, Transport between the troposphere and the stratosphere, J. Geophys. Res., 104, 9123-9139, 1999.

Shindell, D. T., Faluvegi, G., and Bell, N.: Preindustrial-to-presentday radiative forcing by tropospheric ozone from improved simulations with the GISS chemistry-climate GCM, Atmos. Chem. Phys., 3, 1675-1702, 2003.

Shine, K. P.: On the cause of the relative greenhouse strength of gases such as the halocarbons, J. Atmos. Sci., 48, 1513-1518, 1991.

Stamnes, K., Tsay, S.-C., Wiscombe, W., and Jayweera, K.: Numerically stable algorithm for discrete-ordinate-method radiative transfer in multiple scattering and emitting layered media, J. Appl. Opt., 27, 2502-2509, 1998.

Stenke, A. and Grewe, V.: Simulation of stratospheric water vapor trends: impact on stratospheric ozone chemistry, Atmos. Chem. Phys., 5, 1257-1272, 2005.

Stevenson, D. S., Johnson, C. E., Collins, W. J., Derwent, R. G., Shine, K. P., and Edwards, J. M.: Evolution of tropospheric ozone radiative forcing, Geophys. Res. Lett., 25, 3819-3822, 1998.

Stevenson, D. S., Doherty, R. M., Sanderson, M. G., Collins, W. J., Johnson, C. E., and Derwent, R. G.: Radiative forcing from aircraft $\mathrm{NO}_{\mathrm{x}}$ emissions: mechanisms and seasonal dependence, J. Geophys. Res., 109, D17307, doi:10.1029/2004JD004759, 2004.

Stevenson, D. S., Doherty, R. M., Sanderson, M. G., Johnson, C. E., Collins, W. J., and Derwent, R. G.: Impacts of climate change and variability on tropospheric ozone and its precursors, Faraday Discuss., 130, 41-57, doi:10.1039/b417412g, 2005.

Stevenson, D. S., Dentener, F. J., Schultz, M. G., Ellingsen, K., van Noije, T. P. C., Wild, O., Zeng, G., Amann, M., Atherton, C. S., Bell, N., Bergmann, D. J., Bey, I., Butler, T., Cofala, J., Collins, W. J., Derwent, R. G., Doherty, R. M., Drevet, J., Eskes, H. J., Fiore, A. M., Gauss, M., Hauglustaine, D. A., Horowitz, L. W., Isaksen, I. S. A., Krol, M. C., Lamarque, J.-F., Lawrence, M. G., Montanaro, V., Müller, J.-F., Pitari, G., Prather, M. J., Pyle, J. A., Rast, S., Rodriguez, J. M., Sanderson, M. G., Savage, N. H., Shindell, D. T., Strahan, S. E., Sudo, K., and Szopa, S.: Multimodel ensemble simulations of present-day and near-future tropospheric ozone, J. Geophys. Res., in press, 2006.

Stolarski, R., Bojkov, R., Bishop, L., Zerefos, C. S., Staehelin, J., and Zawodny, J.: Measured trends in stratospheric ozone, Science, 256, 342-349, 1992.

Sudo, K., Takahashi, M., Kurokawa, J., and Akimoto, H.: CHASER: A global chemical model of the troposphere 1. Model description, J. Geophys. Res., 107(D17), 4339, doi:10.1029/2001JD001113, 2002a.

Sudo, K., Takahashi, M., and Akimoto, H.: CHASER: A global chemical model of the troposphere 2. Model results and evaluation, J. Geophys. Res., 107 (D21), 4586,
doi:10.1029/2001JD001114, 2002b.

Sudo, K., Takahashi, M., and Akimoto, H.: Future changes in stratosphere-troposphere exchange and their impacts on future tropospheric ozone simulations, Geophys. Res. Lett., 30(24), 2256, doi:10.1029/2003GL018526, 2003.

Sundet, J. K.: Model Studies with a 3-D Global CTM using ECMWF data, PhD thesis, Dept. of Geophysics, University of Oslo, Norway, 1997.

Tiedtke, M.: A Comprehensive Mass Flux Scheme for Cumulus Parameterisation on Large Scale Models, Mon. Wea. Rev., 117, 1779-1800, 1989.

van Leer, B.: Towards the ultimate conservative difference scheme. III. Upstream-centered finite-difference schemes for ideal compressible flow, J. Comput. Phys., 23(3), 263-275, 1977.

van Noije, T. P. C., Eskes, H. J., Dentener, F. J., Stevenson, D. S., Ellingsen, K., Schultz, M. G., Wild, O., Amann, M., Atherton, C. S., Bergmann, D. J., Bey, I., Boersma, K. F., Butler, T., Cofala, J., Drevet, J., Fiore, A. M., Gauss, M., Hauglustaine, D. A., Horowitz, L. W., Isaksen, I. S. A., Krol, M. C., Lamarque, J.F., Lawrence, M. G., Martin, R. V., Montanaro, V., Müller, J.-F., Pitari, G., Prather, M. J., Pyle, J. A., Richter, A., Rodriguez, J. M., Savage, N. H., Strahan, S. E., Sudo, K., Szopa, S., and van Roozendael, M.: Multi-model ensemble simulations of tropospheric NO2 compared with GOME retrievals for the year 2000, Atmos. Chem. Phys. Discuss., accepted, 2006.

Volz, A. and Kley, D.: Evaluation of the Montsouris series of ozone measurements made in the 19th century, Nature, 332(6161), 240-242, 1988.

Wang, W.-C. and Sze, N. D.: Coupled effects of atmospheric N2O and O3 on the Earth's atmosphere, Nature, 286, 589-590, 1980.

Wang, Y. and Jacob, D. J.: Anthropogenic forcing on tropospheric ozone and $\mathrm{OH}$ since preindustrial times, J. Geophys. Res., 103, 31 123-31 135, 1998.

Washington, W. M., Weatherly, J. W., Meehl, G. A., Semtner, A. J., Bettge, T. W., Craig, A. P., Strand, W. G., Arblaster, J., Wayland, V. B., James, R., Zhang, Y.: Parallel climate model (PCM) control and transient simulations, Clim. Dyn., 16, 755-774, 2000.

Wild, O. and Prather, M. J.: Excitation of the primary tropospheric chemical mode in a global CTM, J. Geophys. Res., 105, $24647-$ $24660,2000$.

Wild, O., Sundet, J. K., Prather, M. J., Isaksen, I. S. A., Akimoto, H., Browell, E. V., and Oltmans, S. J.: CTM Ozone Simulations for Spring 2001 over the Western Pacific: Comparisons with TRACE-P Lidar, ozonesondes and TOMS columns, J. Geophys. Res., 108(D21), 8826, doi:10.1029/2002JD003283, 2003.

Williamson, D. L. and Rasch, P. J.: Water vapour transport in the NCAR CCM2, Tellus, 46A, 34-51, 1994.

Wong, S., Wang, W. C., Isaksen, I. S. A., Berntsen, T. K., and Sundet, J. K.: A global climate chemistry model study of presentday tropospheric chemistry and radiative forcing from changes in tropospheric O-3 since the preindustrial period, J. Geophys. Res., 109(D11), D11309, doi:10.1029/2003JD003998, 2004.

WMO (World Meteorological Organization): Scientific Assessment of Ozone Depletion: 2002, Global Ozone Research and Monitoring Project, Report No. 47, 498 pp., Geneva, 2003.

Zhang, G. J. and McFarlane, N. A.: Sensitivity of climate simulations to the parameterization of cumulus convection in the Canadian Climate Centre general circulation model, Atmos. Ocean, 33, 407-446, 1995. 
Zeng, G. and Pyle, J. A.: Changes in tropospheric ozone between 2000 and 2100 modeled in a chemistry-climate model, Geophys. Res. Lett., 30(7), 1392, doi:10.1029/2002GL016708, 2003.

Zeng, G. and Pyle, J. A.: Influence of El Nino Southern Oscillation on stratosphere/troposphere exchange and the global tropospheric ozone budget, Geophys. Res. Lett., 32, L01814, doi:10.1029/2004GL021353, 2005.
Zerefos, C. S.: Long-term ozone and UV variations at Thessaloniki, Greece, Phys. Chem. Earth, 27, 455-460, 2002. 